\title{
Disruption of the Subendothelial Basement Membrane during Neutrophil Diapedesis in an In Vitro Construct of a Blood Vessel Wall
}

\author{
Andreas R. Huber and Stephen J. Weiss \\ Department of Internal Medicine, Division of Hematology and Oncology, Simpson Memorial Research Institute, \\ University of Michigan, Ann Arbor, Michigan 48109
}

\begin{abstract}
To examine the course of physiologic interactions between extravasating neutrophils and the subendothelial basement membrane, a model of the venular vessel wall was constructed by culturing human umbilical vein endothelial cells on a collagen matrix. After $21 \mathrm{~d}$ in culture, the endothelial cell monolayer displayed in vivo-like intercellular borders and junctions, deposited a single-layered, continuous basement membrane that was impenetrable to colloidal particles, and supported neutrophil extravasation in a physiologic manner. Using this model, we demonstrate that neutrophil transmigration in a plasma milieu was associated with a significant disruption of the retentive properties of the basement membrane in the absence of discernable morphologic changes. The loss of basement membrane integrity associated with neutrophil diapedesis was not dependent on neutrophil elastase or cathepsin $\mathbf{G}$ and was resistant to inhibitors directed against neutrophil collagenase, gelatinase, and heparanase. Despite the fact that this loss in matrix integrity could not be prevented, basement membrane defects were only transiently expressed before they were repaired by the overlying endothelium via a mechanism that required active protein and RNA synthesis. These data indicate that neutrophil extravasation and reversible basement membrane disruption are coordinated events that occur as a consequence of vessel wall transmigration.
\end{abstract}

\section{Introduction}

In response to an inflammatory stimulus originating within the interstitium, circulating neutrophils rapidly traverse the vessel wall of the postcapillary venule and invade the surrounding tissues (1). To accomplish this task, triggered neutrophils adhere to the apical surface of the endothelial cell layer and migrate between interendothelial cell junctions until they arrive at the underlying basement membrane (1). The basement membrane is a tough, thin, highly distensible matrix that maintains venule architecture (2-4), regulates endothelial cell adhesion and mitogenesis $(5,6)$, acts as a depository for growth factors, proteinases, proteinase inhibitors, and thrombotic agents (7-11), and participates in the control of the selective filtration characteristics of the vessel wall $(3,12,13)$. As the extravasating neutrophil reaches this structural barrier, histo-

Address reprint requests to Dr. Stephen J. Weiss, Simpson Memorial Research Institute, 102 Observatory Street, Ann Arbor, MI 48109.

Received for publication 22 July 1988 and in revised form 30 November 1988.

J. Clin. Invest.

(C) The American Society for Clinical Investigation, Inc.

$0021-9738 / 89 / 04 / 1122 / 15 \$ 2.00$

Volume 83, April 1989, 1122-1136 logic studies have uniformly found that the cell pauses, and that its continued emigration is delayed until the matrix is successfully penetrated (1, 14-18). Interestingly, microscopic examinations of vessel walls exposed to neutrophil traffic in vivo have failed to consistently identify defects or alterations in basement membrane structure (14-18). The mechanisms used by the neutrophil to traverse this barrier are unknown, but the ability of neutrophils to adhere to the subendothelial basement membrane in vitro and to degrade its structural components has been the subject of a number of recent reports (19-22). However, in each of these studies neutrophils were triggered atop denuded matrices that had been deposited onto solid surfaces. Under these conditions chemotactic gradients could not be generated nor neutrophil emigration accommodated. At present, almost nothing is known with regard to the events surrounding the interaction between extravasating neutrophils and the subendothelial basement membrane in a physiologic setting (1).

One of the primary obstacles to an in vitro analysis of neutrophil transmigration is the fact that a three-dimensional model of the vessel wall that mimics the structural and functional features of the postcapillary venule is required. Although a number of model systems have been designed to study neutrophil migration (e.g., references 23-27), recent studies suggest that key structural and functional characteristics of cultured endothelial cell monolayers may have been overlooked $(28,29)$. Indeed, with special relevance to studies of cell emigration, it has proven especially difficult to establish in vitro conditions wherein endothelial cells synthesize a functionally intact basement membrane (28). In the absence of this structural barrier, analyses of invasive processes are of questionable significance. From this perspective, we now describe a homologous, in vitro construct of the venular vessel wall in which a confluent monolayer of endothelial cells displays in vivo-like intercellular borders and junctions, secretes a singlelayered, continuous basement membrane that is impenetrable to small, colloidal particles, and supports neutrophil extravasation in a physiologic setting and manner. Using this model, we have demonstrated that $(a)$ neutrophil transmigration across a vessel wall construct in a plasma milieu is associated with a significant disruption of the barrier function of the subendothelial basement membrane, $(b)$ this disruptive process occurs independently of neutrophil elastase or cathepsin $\mathrm{G}$ and is resistant to high concentrations of either metalloproteinase or endoglycosidase inhibitors, and $(c)$ basement membrane defects are only transiently expressed before they are repaired by the overlying endothelial cells via a mechanism that requires both active protein and RNA synthesis.

\section{Methods}

\section{Construct of the vessel wall model}

Human umbilical vein endothelial cells were isolated according to a modification of the technique described by Gimbrone (30). Briefly, 
endothelial cells were isolated from 3-5 umbilical cords with 150 $\mathrm{U} / \mathrm{mg}$ 0.05\% collagenase (CLS type 3; Worthington Biochemical Corp., Freehold, NJ), pooled, and suspended in M199 (Gibco Laboratories, Grand Island, NY) supplemented with $20 \%$ pooled human serum, 2 mM L-glutamine (Sigma Chemical Co., St. Louis, MO), 100 $\mathrm{U} / \mathrm{ml}$ penicillin (Pfizer, Inc., New York, NY), $50 \mu \mathrm{g} / \mathrm{ml}$ streptomycin (Pfizer, Inc.), and $0.25 \mu \mathrm{g} / \mathrm{ml}$ amphotericin B (E. R. Squibb and Sons, Inc., Princeton, NJ). Cells were cultured in $4.9-\mathrm{cm}^{2}$ double chamber culture dishes (Transwell 3414; Costar, Cambridge, MA) in which the polycarbonate membrane ( $3-\mu \mathrm{m}$ pore size) had first been overlaid with a hydrated, type I collagen gel. Collagen was extracted from rat tails as described (31) and dialyzed overnight against a $0.05 \mathrm{M}$ tris(hydroxymethyl)-aminomethane hydrochloride (Tris- $\mathrm{HCl}$ ) $-0.2 \mathrm{M} \mathrm{NaCl}$ buffer $(\mathrm{pH} 7.6)$ at $4^{\circ} \mathrm{C} .1 \mathrm{ml}$ of the collagen $(2 \mathrm{mg} / \mathrm{ml})$ was transferred in the cold to the upper chamber of the Transwell dish and allowed to gel for $30 \mathrm{~min}$ at $37^{\circ} \mathrm{C}$ in a $95 \%$ air $/ 5 \% \mathrm{CO}_{2}$ humidified atmosphere. The collagen gels were then preincubated with culture media for $2 \mathrm{~h}$ before use. At this time endothelial cells $\left(5 \times 10^{4}\right)$ were added to the collagencoated upper chamber and cultured for 19-21 d in the presence of 75 $\mu \mathrm{g} / \mathrm{ml}$ endothelial cell growth supplement (Collaborative Research, Inc., Lexington, MA) and $50 \mu \mathrm{g} / \mathrm{ml}$ ascorbic acid (Sigma Chemical Co.) with media changes every $3 \mathrm{~d}$ (the final volumes of the upper and lower chambers were 1 and $3 \mathrm{ml}$, respectively). Endothelial cells formed a confluent monolayer on the type I collagen gel within $5 \mathrm{~d}$. Because a serum and growth factor-supplemented medium might mimic a wound-like environment (32), the culture medium was changed to M199 containing 20\% heat-inactivated plasma without growth supplement or antibiotics (33) $2 \mathrm{~d}$ before the cultures were used for experiments. Heat-inactivated plasma was prepared from heparinized blood $(5 \mathrm{U} / \mathrm{ml}$ of endotoxin- and preservative-free heparin; Sigma Chemical Co.) that had been centrifuged $\left(27,000 \mathrm{~g}\right.$ for $5 \mathrm{~min}$ at $\left.4^{\circ} \mathrm{C}\right)$, incubated at $56^{\circ} \mathrm{C}$ for $40 \mathrm{~min}$, and centrifuged again $(27,000 \mathrm{~g}$ for 20 $\mathrm{min})$. At the end of the $21-23-\mathrm{d}$ culture period, the media always contained $<0.02 \mathrm{ng} / \mathrm{ml}$ endotoxin as determined by limulus amebocyte lysate testing (Whittaker M. A. Bioproducts, Walkersville, MD).

\section{Morphology of vessel wall construct}

Silver nitrate staining of cultures. Cultures (21-23 d) were stained with silver nitrate as described by Furie et al. (34).

Electron microscopy. Cultures were washed with HBSS and immediately fixed in situ with $1.25 \%$ glutaraldehyde (Polysciences, Inc., Warrington, PA) in $0.1 \mathrm{M}$ cacodylate (Polysciences, Inc.), $0.12 \mathrm{M}$ sucrose, $2 \mathrm{mM} \mathrm{CaCl}$, $\mathrm{pH} 7.3$ (hereafter referred to as cacodylate buffer), and $1 \%$ osmium tetroxide (Sigma Chemical Co.) for $2 \mathrm{~h}$ at $4^{\circ} \mathrm{C}$ (35). In selected experiments $3 \mathrm{mg} / \mathrm{ml}$ ruthenium red (Sigma Chemical Co.) was added to the fixative (36). Cultures were then washed with cacodylate buffer and treated with $1 \%$ tannic acid (Mallinckrodt, Inc., St. Louis, MO) and $1 \% \mathrm{Na}_{2} \mathrm{SO}_{4}$ according to the method of Simionescu (37). For transmission electron microscopy, the samples were washed in cacodylate buffer, dehydrated in ethanol, and embedded in epoxyresin (Polysciences, Inc.). Ultrathin sections $(60 \mathrm{~nm})$ were poststained with uranyl acetate and lead nitrate and viewed on an electron microscope (model 400; Philips Electronic Instruments, Inc., Mahwah, NJ). Junctional details of freeze fracture replicas were examined according to the technique of Pauli et al. (38). For scanning electron microscopy, samples were dehydrated in ethanol, twice immersed in hexamethyldisilazane (Polysciences, Inc.), and dried (39). The samples were gold sputtered on a Polaron II (Polaron Instruments, Inc., Hatfield, PA) and examined on a scanning electron microscope (model ICI-DS-130; International Scientific Instruments Inc., Santa Barbara, CA).

\section{Characterization of the subendothelial basement membrane}

Isolation of the subendothelial matrix. Basement membranes were denuded after a mild detergent lysis of the endothelial cells by a modification of the technique of Kramer et al. (40). After a single wash with PBS containing $0.1 \%$ BSA (Sigma Chemical Co.), the cultures were immersed in a hypotonic buffer ( $10 \mathrm{mM}$ Tris- $\mathrm{HCl}, 0.1 \% \mathrm{BSA}, 0.1 \mathrm{mM}$ $\mathrm{CaCl}_{2}, 1 \mathrm{mM}$-ethylmaleimide, $1 \mathrm{mM}$ PMSF, and $5 \mathrm{mM}$ EDTA, $\mathrm{pH}$ 7.5) and incubated for $10 \mathrm{~min}$ at $37^{\circ} \mathrm{C}$. The endothelial cells were then lysed during a 2-min incubation with $0.5 \%$ NP-40 detergent (Sigma Chemical Co.) in hypotonic buffer at $37^{\circ} \mathrm{C}$. The matrices were immersed in hypotonic buffer containing $0.2 \%$ deoxycholate (Sigma Chemical Co.) to remove residual debris.

Biosynthetic labeling of the subendothelial matrix. 20-d-old cultures were washed with HBSS and incubated with $30 \mu \mathrm{Ci} / \mathrm{ml}\left[{ }^{3} \mathrm{H}\right]-$ proline ( $100 \mathrm{Ci} / \mathrm{mmol}$; DuPont New England Nuclear, Boston, MA) in proline-free M199 (KC Biological Inc., Lenexa, KS) containing 20\% heat-inactivated plasma, $50 \mu \mathrm{g} / \mathrm{ml}$ ascorbic acid (Sigma Chemical Co.), and $80 \mu \mathrm{g} / \mathrm{ml} \beta$-aminoproprionitrile (Sigma Chemical Co.) for $24 \mathrm{~h}$ (41). The cultures were then washed and the basement membrane denuded as described above. Matrices were solubilized and reduced in an SDS buffer ( $50 \mathrm{mM}$ Tris- $\mathrm{HCl}, 5 \% \beta$-mercaptoethanol, $1 \%$ SDS, $\mathrm{pH}$ $7.5)$ by heating to $100^{\circ} \mathrm{C}$ for $3 \mathrm{~min}$. SDS-PAGE was performed with a $3 \%$ stacking and $5 \%$ running gel containing $0.5 \mathrm{M}$ urea as described (41). In selected experiments matrices were incubated with $3 \mathrm{U} / \mathrm{ml}$ purified bacterial collagenase (form III; Advance Biofactures, Lynbrook, NY) for $18 \mathrm{~h}$ at $37^{\circ} \mathrm{C}$ before solubilization (41).

Colloid permeability of the subendothelial basement membrane. The ability of basement membranes to retain a colloidal pigment was determined by adding $3 \mathrm{ml}$ of a $0.03 \%$ solution of monastral blue B (copper phthalocyanine with a particle size up to $500 \AA$, [42]; Sigma Chemical Co.) in cold HBSS (calcium- and magnesium-free, containing $1 \mathrm{mM} N$-ethylmaleimide, $1 \mathrm{mM}$ PMSF, and $1 \mathrm{mM}$ EDTA) to the upper compartment of Transwell culture dishes containing a previously denuded matrix (the lower compartment was filled with $2 \mathrm{ml}$ of an identical buffer without monastral blue). The samples were then incubated for $10 \mathrm{~h}$ at $4^{\circ} \mathrm{C}$. At the end of the incubation period the cultures were washed two times (to remove any pigment adherent to the matrix surface) and either paraffin-embedded for light microscopy or digested with bacterial collagenase (CLS type 3, Worthington Biochemical Corp.; $50 \mu \mathrm{g} / \mathrm{ml}$ in $50 \mathrm{mM}$ Tris- $\mathrm{HCl}, 4 \mathrm{mM} \mathrm{CaCl}, \mathrm{pH} 8.0$ ) for spectrophotometric analysis. The quantity of monastral blue trapped in the underlying type I collagen matrix was based on the calculated extinction coefficient for the absorbance change at $605 \mathrm{~nm}$ minus $525 \mathrm{~nm}$ of a $1 \%$ solution (in a $1-\mathrm{cm}$ light path) of 340 . In selected experiments basement membrane integrity was alternatively assessed by exposing the underlying matrix without a detergent lysis step by treating the endothelial cell monolayers for 10 min with $2.5 \mathrm{mM}$ EGTA in calcium- and magnesium-free HBSS (43). The retracted monolayer was then overlaid with a solution of $0.03 \%$ monastral blue that contained $2.5 \mathrm{mM}$ EGTA for $10 \mathrm{~h}$ at $4^{\circ} \mathrm{C}$ as described.

\section{Neutrophil emigration across the vessel wall construct}

Neutrophil preparation. Neutrophils were isolated from peripheral venous blood under sterile conditions by Ficoll-diatrizoate density centrifugation and dextran sedimentation as previously described (44). Only lots of Ficoll-diatrizoate (Histopaque-1077; Sigma Chemical Co.) and dextran $(250,000 \mathrm{~mol} w \mathrm{w}$; ICN Nutritional Biochemicals, Cleveland, $\mathrm{OH}$ ) that contained $<0.1 \mathrm{ng} / \mathrm{ml}$ endotoxin were used. Isolated neutrophils were suspended in HBSS containing 20\% heat-inactivated autologous plasma. In selected experiments neutrophils were pretreated with $5 \mathrm{mM}$ diisopropylfluorophosphate (DFP'; Sigma Chemical Co.) for $1 \mathrm{~h}$ at $25^{\circ} \mathrm{C}$. The cells were then washed extensively and suspended in HBSS. DFP-treated neutrophils contained $<1 \%$ residual elastase activity and $<3 \%$ cathepsin $G$ activity as determined in Triton $\mathrm{X}-100$ lysates (assessed as amidase activity [44] with methoxysuccinyl-ala-ala-pro-val-paranitroanilide and methoxysuccinyl-ala-alapro-phe-paranitroanilide [Calbiochem-Behring Corp., La Jolla, CA], respectively).

1. Abbreviations used in this paper: DFP, diisopropylfluorophosphate; TIMP, tissue inhibitor of metalloproteinases. 
Migration studies. Neutrophil migration studies were initiated by placing $3 \mathrm{ml}$ HBSS containing either $20 \%$ heat-inactivated autologous plasma or zymosan-activated, autologous plasma in the lower compartment of the Transwell dish and $10^{6}$ neutrophils in a final vol of 1 $\mathrm{ml}$ to the upper compartment. Zymosan-activated plasma, used as a source of chemotactic activity (45), was prepared by incubating plasma with boiled and washed zymosan particles $(12.5 \mathrm{mg} / \mathrm{ml}$ plasma; ICN Biomedicals, Inc., Costa Mesa, CA) for $45 \mathrm{~min}$ at $37^{\circ} \mathrm{C}$. The zymosan particles were then pelleted $(1,000 \mathrm{~g}$ for $5 \mathrm{~min})$ and the plasma was removed, heated to $56^{\circ} \mathrm{C}$ for $30 \mathrm{~min}$, centrifuged $(27,000 \mathrm{~g}$ for $20 \mathrm{~min}$ ), and sterile-filtered.

At indicated time points the number of neutrophils that were associated with the vessel wall (i.e., cells that were firmly bound to the endothelial cell surface or that had penetrated the monolayer) was quantitied by removing the medium from the upper compartment and rapidly washing the monolayer surface two times with calcium- and magnesium-free HBSS containing $5 \mathrm{mM}$ EDTA. The three washes were pooled and the number of recovered neutrophils determined by electronic cell counting (Coulter Electronics Inc., Hialeah, FL). This treatment did not detach endothelial cells from the monolayer. Leading front measurements were performed according to the method of Zigmond and Hirsch (46) by measuring the distance between the surface of the endothelial cell monolayer and the four most distant neutrophils in four random fields (magnified 100 times) by phase microscopy. ${ }^{2}$

In selected experiments migration studies were performed with cultures that were preincubated with either $10 \mu \mathrm{g} / \mathrm{ml}$ cycloheximide (Sigma Chemical Co.), $10 \mu \mathrm{g} / \mathrm{ml}$ actinomycin D (Sigma Chemical Co.), $10-20 \mu \mathrm{g} / \mathrm{ml}$ porcine intestine or bovine lung heparin (Calbiochem-Behring Corp.), recombinant human fibroblast tissue inhibitor of metalloproteinases (TIMP; a gift from Synergen, Inc., Boulder, CO), benzamidine, $\epsilon$-aminocaproic acid, aprotinin, leupeptin, pepstatin, or phosphoramidon (each of these agents were obtained from Sigma Chemical Co.) for $30 \mathrm{~min}$ before the addition of neutrophils. All agents were added to both the upper and lower compartments and were present in the medium throughout the course of the incubation period. Neutrophils were also preincubated with the agents for $30 \mathrm{~min}$ before being added to the vessel wall constructs.

\section{Results}

Characteristics of the vessel wall construct. After $21 \mathrm{~d}$ in culture endothelial cells consistently formed a homogeneous and confluent monolayer whose intercellular borders stained with silver nitrate (Figs. 1, $A$ and $B$ ) (47). After treating the monolayers with ruthenium red, electron microscopy revealed the characteristic $\sim 30$-nm-thick endothelial cell glycocalyx (36) (micrograph not shown). Short, circumscript fusions of the outer leaflets of the plasma membranes were also detected in the electron micrographs (Fig. 2) and freeze-fracture replicas of these junctions revealed simple, discontinuous, low profile ridges characteristic of the "leaky" tight junctions observed in small veins and venules (Fig. 2, inset) (47). Interestingly, gap junctions and complex junctional arrangements, structures normally present in adult large vein endothelial cells, were not observed in the cultured umbilical vein endothelial cells (47).

Under almost all culture conditions, endothelial cells have been reported to synthesize a discontinuous, multilayered extracellular matrix $(28,29)$. However, in vivo, endothelial cells are known to secrete a continuous basement membrane that

2. The polycarbonate filter used in the Transwell design is normally rendered opaque to microscopy during sterilization by radiation. However, if the dishes are purchased nonsterile and treated with ethylene oxide, the filters remain transparent. by electron microscopy appears as a bilayer of electron-dense and translucent layers $(28,47)$. The electron-dense layer is termed the lamina densa while the translucent layer (which can be stained with ruthenium red) is termed the lamina rara (47). As shown in Fig. $3 \mathrm{~A}$, endothelial cells cultured for $21 \mathrm{~d}$ on a type I collagen matrix secreted a subendothelial basement membrane that appeared by microscopy as a lamina densalike monolayer closely apposed to the abluminal surface of the endothelial cells. After lysis of the cells, staining of the basement membrane with ruthenium red revealed the otherwise invisible lamina rara of the subendothelial matrix (Fig. $3 \mathrm{~B}$ ) (47). Scanning electron micrographs of the denuded monolayer confirmed the presence of a continuous basement membrane that could be easily differentiated from the underlying type I collagen matrix (Fig. 4). If monolayers were cultured for $<21 \mathrm{~d}$, discontinuities in the basement membrane were frequently observed (data not shown).

In vivo, the major collagenous component of the basement membrane is type IV collagen (12). To confirm its presence in the deposited basement membrane, radiolabeled vessel wall constructs were denuded, extracted, and examined by SDSPAGE fluorography. As shown in Fig. 5, a closely migrating doublet band with an $M_{\mathrm{r}}$ of $\sim 180,000$ consistent with that of type IV collagen was observed (lane 1$)(40,41)$. As expected, if the denuded matrix was treated with highly purified bacterial collagenase before extraction, the $M_{\mathrm{r}} 180,000$ band disappeared, confirming its collagenous composition (Fig. 5) (41). The other major radiolabeled bands with $M_{\mathrm{r}} s$ of $\sim 230,000$ and 150,000 comigrated with fibronectin and thrombospondin, respectively (data not shown). ${ }^{3}$

Thus far, the synthesized basement membrane appeared morphologically correct and contained many of the expected structural components. However, in vivo, the basement membrane possesses a macromolecular composition that restricts the passage of $300-500 \AA$ colloidal particles from the vascular bed into the interstitium $(3,42,50)$. To ascertain whether the basement membrane synthesized by the cultured endothelial cells expressed a similar barrier potential, denuded basement membranes were overlaid with colloidal particles for $10 \mathrm{~h}$, washed, and examined by light microscopy. As shown in Fig. 6 $A$, the pigment did not penetrate the continuous basement membrane. In contrast, when colloidal pigment was placed over a control type I collagen gel (i.e., a collagen gel placed in culture for $21 \mathrm{~d}$ in the absence of éndothelial cells), the pigment readily penetrated into the matrix (Fig. $6 \mathrm{~B}$ ). Taken together, these data demonstrate that the vessel wall construct has morphologic, structural, and barrier characteristics that closely mimic those found in vivo.

Barrier function of the basement membrane to extravasating neutrophils. In vivo, emigrating neutrophils invade the endothelial cell layer and pause atop the basement membrane

3. Although a similar pattern has been reported in extracts of subendothelial matrices synthesized by human microvascular endothelial cells, laminin, an additional basement membrane component, cannot be readily detected on SDS gels in these or other systems $(40,41,48)$. Gospodarowicz et al. have demonstrated that unlike actively proliferating cultures of endothelial cells, confluent monolayers secrete only small amounts of laminin into the medium (49), while Kramer and colleagues have suggested that laminin may be cross-linked with other basement membrane components to form large complexes that do not penetrate into SDS gels $(40,41)$. 

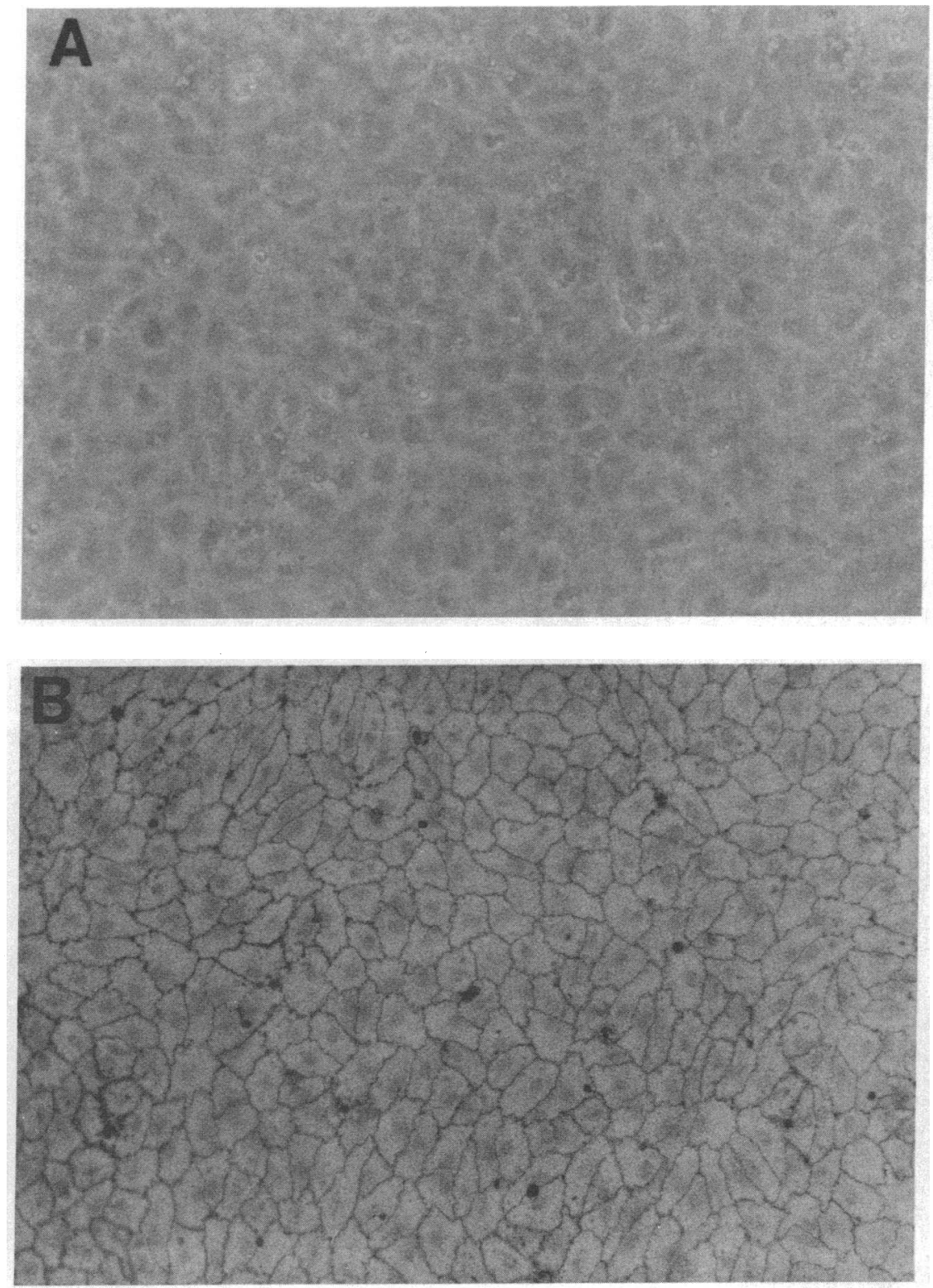

Figure 1. Micrographs of human umbilical vein endothelial cells cultured for $21 \mathrm{~d}$ on the surface of a type I collagen support. (A) Phase contrast photomicrograph of a control endothelial cell monolayer. $(B)$ Light micrograph of endothelial cell culture stained with $\mathrm{AgNO}_{3}$. Photomicrographs are shown at $\times 625$ for $A$ and $B$. until pseudopodia begin to extend through the matrix (1, 14-18). To determine whether the basement membrane synthesized by cultured endothelial cells retarded neutrophil movement in a similar fashion, the ability of emigrating neutrophils to transmigrate the vessel wall construct was monitored. In response to the addition of zymosan-activated plasma to the lower compartment, neutrophils $\left(1 \times 10^{6}\right)$ added to the upper compartment rapidly adhered to the surface of the endothelial cell monolayer (Fig. $7 A$ ). At $0.5 \mathrm{~h}, \sim 50 \%$ of the neutrophils were vessel wall associated and after a 2-h incubation this value increased to $>80 \%$ (Fig. $7 \mathrm{~A}$ ). At the $2-\mathrm{h}$ time point, light microscopic examination of cross-sections taken through the vessel wall construct revealed that almost all of the neutrophils could be found in the supporting matrix of interstitial collagen (Fig. 8). Indeed, if the incubation time was increased to $18 \mathrm{~h}, 43.3 \pm 2.8 \%(n=5)$ of the neutrophils continued to migrate through the interstitial collagen to eventually accumulate in the lower compartment of the culture well (the remainder of the migrated cells were trapped in the interstices of the type I collagen matrix). In contrast, if heat-inactivated plasma was added to the lower compartment, almost all of the neutrophils could be recovered in the fluid phase of the upper chamber (Fig. $7 A$ ) and few if any neutrophils penetrated the endothelial cell layer (not shown).

To assess the kinetics of neutrophil migration, cell movement was quantitated by the leading front technique. As shown in Fig. $7 B$, neutrophil emigration proceeded slowly during the first $0.5-\mathrm{h}$ incubation period $(\sim 30 \mu \mathrm{m} / \mathrm{h})$, but then accelerated to $\sim 125 \mu \mathrm{m} / \mathrm{h}$, a rate that was maintained for at least the next $4 \mathrm{~h}$. At $2 \mathrm{~h}$ migrating neutrophils penetrated the vessel wall construct to a mean depth of $220 \pm 23 \mu \mathrm{m}$, which compared with $38 \pm 10 \mu \mathrm{m}$ for resting cells. An examination of neutrophil morphology (as assessed by phase contrast microscopy) during the first 30 min of extravasation revealed a highly reproducible pattern in which neutrophils first spread atop the endothelial cells, rapidly disappeared (or appeared as small, phase-translucent globules), and then quickly reappeared as large, phase-dense "pancakes" beneath the endothelial cell 

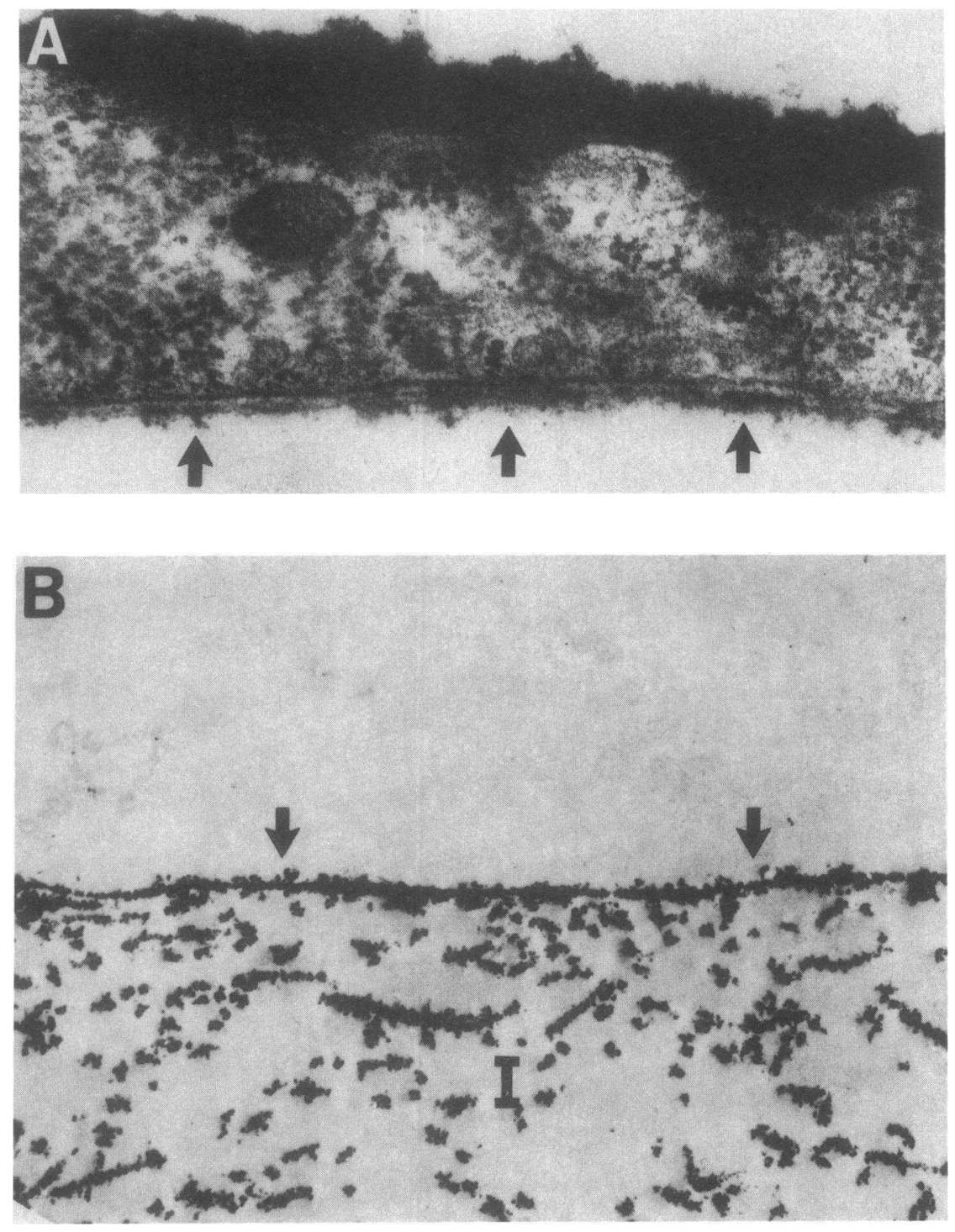

Figure 2. Deposition of a subendothelial basement membrane by endothelial cells cultured on a type I collagen support for $21 \mathrm{~d}$. (A) An electron micrograph reveals an electron-dense layer adjacent to the abluminal side of the endothelial cell monolayer (arrows). (B) An electron micrograph of a ruthenium red-stained, denuded basement membrane synthesized by cultured endothelial cells. Endothelial cells were detergent lysed as described and the exposed basement membrane stained with ruthenium red. The stained basement membrane appears as a dark, continuous band overlying the collagen support (the interstitial collagen support is labeled $I$ ). The micrographs are shown at $\times 52,500(A)$ and $\times 4,200$ (B). monolayer. The subendothelial neutrophils maintained this distinct, spread morphology for $\sim 20-30 \mathrm{~min}$ before they reassumed their globular shape and moved into the underlying type I collagen matrix. Because this spread morphology suggested that the neutrophils might be lying atop the subendothelial basement membrane, vessel wall constructs were incubated with extravasating neutrophils for $30 \mathrm{~min}$, fixed, and processed for microscopy. Indeed, large numbers of neutrophils could be observed in the predicted position atop the apical surface of the basement membrane at this time point (not shown). Thus, the vessel wall construct supported neutrophil diapedesis in a physiologic setting and the subendothelial basement membrane acted, as in vivo, as a transient barrier to the emigrating neutrophil.

Disruption of the endothelial cell basement membrane coincident with neutrophil diapedesis. The fact that emigrating neutrophils pause at the surface of the subendothelial basement membrane has led to the suggestion that neutrophils engage in the active disruption of this barrier before penetrating into the interstitium. Nonetheless, neutrophil diapedesis has not been associated with visible changes in vessel wall structure in vivo (15-18). To ascertain whether basement membrane alterations could be detected on a morphologic level in vitro, $1 \times 10^{6}$ neutrophils were placed in the upper compartment of the vessel wall constructs with either heat-inactivated or zymosan-activated plasma in the lower compartment and incubated for $1 \mathrm{~h}$. At the end of the incubation period the monolayers were washed, the endothelial cells were lysed in the presence of a cocktail of proteinase inhibitors, and the exposed basement membrane was examined by scanning electron microscopy. As shown in Fig. $9 \mathrm{~A}$, basement membranes prepared from vessel wall constructs that had been incubated with resting neutrophils appeared completely normal (compare Fig. $4 \mathrm{~A}$ ). Surprisingly, basement membranes prepared from vessel walls that had been transmigrated by large numbers of neutrophils did not display focal defects despite the fact that "hillocks" formed by the underlying neutrophils could easily be discerned (Fig. $9 \mathrm{~B}$ ). In only one of seven experiments were well-demarcated holes in the basement membrane observed (Fig. $9 C$ ). However, because this was an inconstant finding, convincing morphologic evidence supporting the generation of focal breaches in the basement membrane were not obtained.

In the absence of a consistent morphologic change in 


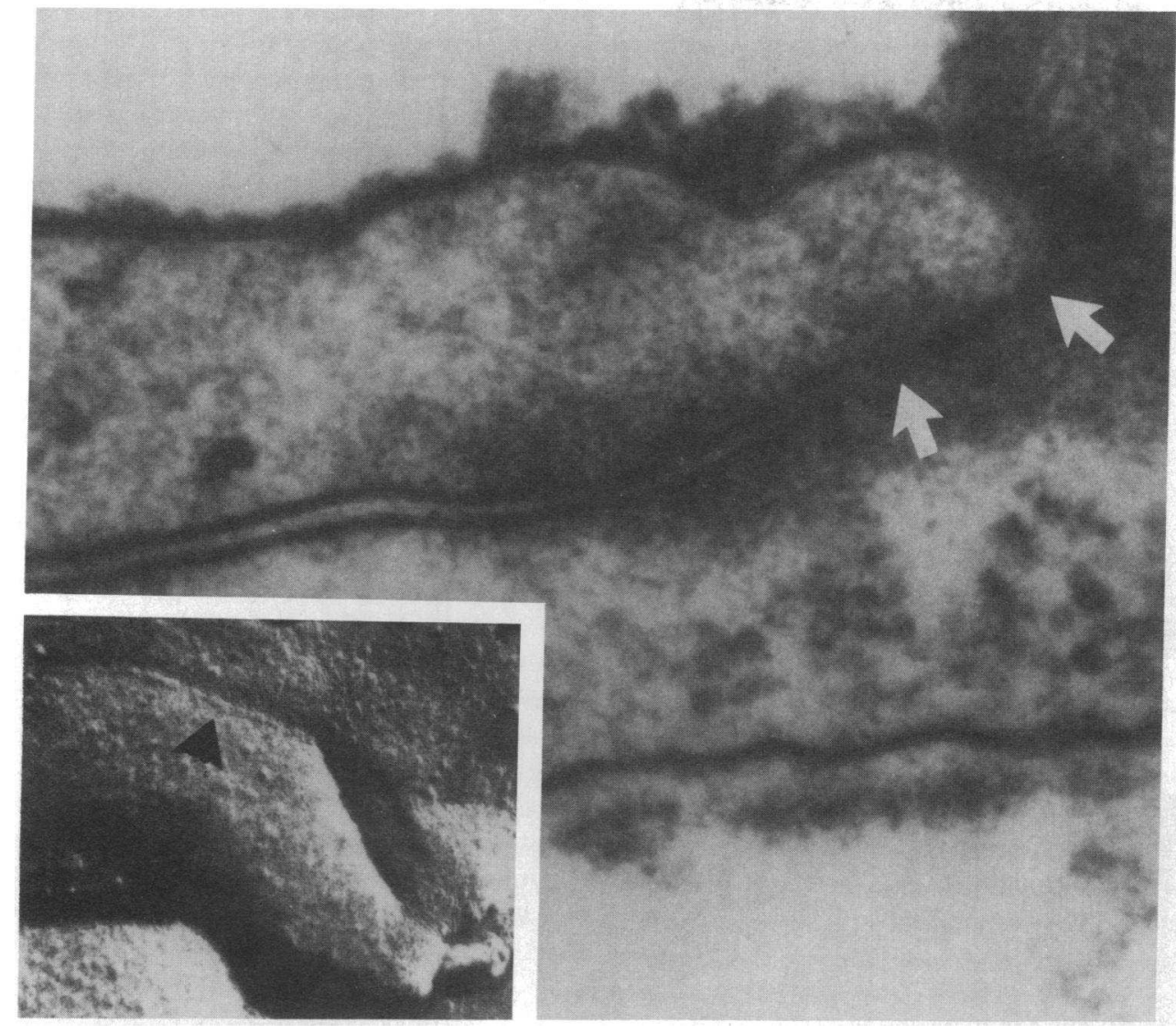

Figure 3. Transmission electron micrograph of a cross-section through an interendothelial cell junction in the vessel wall construct. Fusions of the outer leaflet of the unit membranes are identified by the arrows. (Inset) Electron micrograph of a freeze fracture replica of the vessel wall reveals a low profile junctional strand and groove (arrowhead). The micrographs are shown at $\times 187,500$ for the cross section and $\times 82,800$ for the freeze fracture. transmigrated basement membranes in vivo or in vitro, one could posit that $(a)$ the matrix behaved as a reversibly deformable latticework that the neutrophil mechanically displaced, or (b) stable matrix defects were present, but their changes either were masked during the fixation process or were too subtle to be detected microscopically. Based on the fact that the basement membrane synthesized by the cultured endothelial cells normally excluded monastral blue (see Fig. $6 \mathrm{~A}$ ), the barrier function of the matrix isolated from vessel walls after transmigration was examined for structural defects that might have escaped morphologic detection. As shown in Fig. 10, if an intact vessel wall construct was incubated with resting neutrophils (i.e., heat-inactivated plasma in the lower compartment) for $1 \mathrm{~h}$, the monolayer lysed, overlaid with monastral blue for $10 \mathrm{~h}$, and washed, light micrographs revealed that only small amounts of the blue pigment were associated with the surface of the denuded basement membrane. In marked contrast, if the vessel wall construct was incubated with emigrating neutrophils, the isolated basement membrane lost its ability to exclude the colloid and allowed large amounts of monastral blue to leak into the underlying type I collagen matrix (Fig. 10). As expected, a matrix of plain type I collagen failed to exclude the pigment and stained intensely with the blue colloid (Fig. 10). Thus, despite the absence of gross morphologic changes, the transmigrated basement membrane had undergone a major alteration in one of its functional properties.

To accurately quantitate the colloid leak, the type I collagen supports were digested with bacterial collagenase and the amount of trapped pigment determined spectrophotometrically (see Methods). Basement membranes prepared from cultures that had been traversed by neutrophils for $1 \mathrm{~h}$ allowed
84.6 $\pm 11.0 \mu \mathrm{g}$ of the colloid to leak into the interstitial matrix while control cultures, i.e., vessel walls incubated alone or with resting neutrophils, leaked $4.7 \pm 1.6 \mu \mathrm{g}$ and $8.6 \pm 4.5 \mu \mathrm{g}$ (mean $\pm 1 \mathrm{SEM} ; n=5$ ), respectively. The permeability of basement membranes prepared from cultures incubated with zymosan-activated plasma alone or with neutrophils and zymosan-activated plasma together in the upper compartment were not different from resting neutrophil controls (data not shown).

Because monastral blue is too large to penetrate normal interendothelial cell junctions $(13,50)$, structural changes in basement membrane integrity could only be assessed if the underlying matrix was first exposed. Although detergent lysis of the overlying endothelial cells was chosen as the routine method for exposing the basement membrane, almost identical results were obtained if cultures were treated with EGTA, a chelator that causes endothelial cells to reversibly retract (43). In three experiments, transmigrated cultures treated with EGTA and then overlaid with colloid leaked $68.2 \pm 4.0 \mu \mathrm{g}$ of monastral blue, while cultures incubated with resting neutrophils leaked $10.0 \pm 2.0 \mu \mathrm{g}$ (mean \pm 1 SEM). Thus, regardless of the method chosen for exposing the basement membrane, the barrier function of the subendothelial matrix was significantly compromised after neutrophil diapedesis.

Although the colloid leak revealed the presence of basement membrane defects, additional structural changes might have occurred in the underlying type I collagen matrix. However, in contrast with the results obtained with basement membranes, naked matrices of type I collagen that were incubated alone or with migrating neutrophils leaked identical amounts of monastral blue. In four paired experiments, naked 

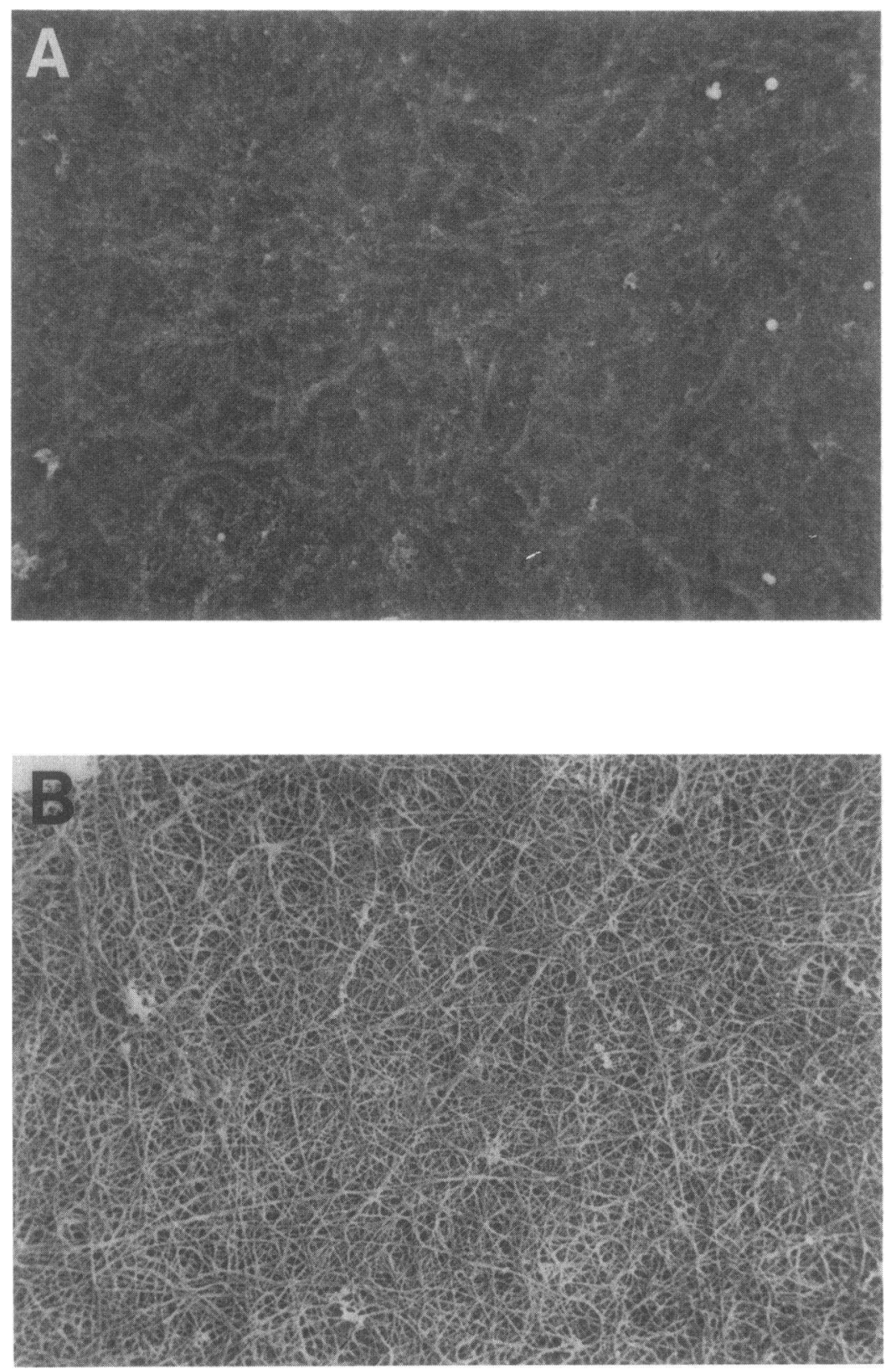

Figure 4. Scanning electron micrographs of the denuded subendothelial basement membrane. $(A) \mathrm{A}$ low power magnification of a 21-d-old, denuded vessel wall construct reveals a continuous, dense basement membrane with a fibrillar appearance (micrograph shown at $\times 1,500$ ). (B) A scanning electron micrograph of the surface of a type I collagen support cultured for $21 \mathrm{~d}$ under identical conditions, but in the absence of endothelial cells (micrograph shown at $\times 1,500)$.

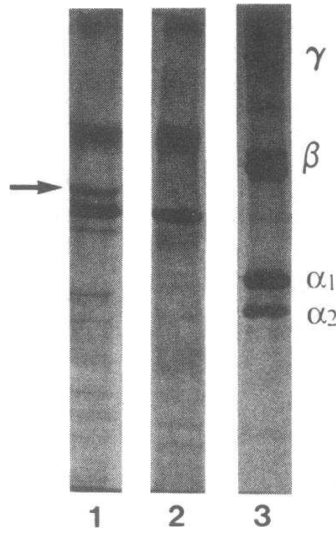

Figure 5. Fluorogram of $\left[{ }^{3} \mathrm{H}\right]$ prolinelabeled proteins deposited into the basement membrane by endothelial cells in the vessel wall construct. A 20-d-old culture was labeled with $\left[{ }^{3} \mathrm{H}\right.$ ]proline for $24 \mathrm{~h}$ in the presence of $\beta$-aminoproprionitrile as described. The vessel construct was then washed and denuded. The remaining basement membrane and the underlying type I collagen support were incubated alone or with bacterial collagenase for $10 \mathrm{~h}$ then solubilized and processed for electrophoresis as described. Samples from the control and bacterial collagenase-treated matrices are shown in lanes $I$ and 2 , respectively. The $M_{\mathrm{r}} 180,000$ material (identified with an arrow) was sensitive to bacterial collagenase. Two faint bands that migrated similarly to the $\alpha$ and $\beta$ bands of type I collagen were also sensitive to collagenase. A radiolabeled type I collagen control is shown in lane 3. type I collagen matrices that had been incubated with $10^{6}$ neutrophils in the upper compartment and zymosan-activated plasma in the lower compartment leaked 179.9 $\pm 5.0 \mu \mathrm{g}$ of colloid $(67 \pm 2 \%$ of the neutrophils invaded the collagen during a 1 $h$ incubation with a leading front of $214 \pm 25 \mu \mathrm{m}$ ) while control collagen matrices leaked $175.2 \pm 4.0 \mu \mathrm{g}$ of the colloid (mean \pm 1 SEM). Thus, the quantitable increases in colloid permeability that occurred in the vessel wall constructs were mediated via alterations in the basement membrane itself.

Effect of lysosomal enzyme inhibitors on neutrophil-dependent basement membrane disruption and emigration. As thus far demonstrated, basement membrane disruption readily occurred in the presence of $20 \%$ plasma, a rich source of proteinase inhibitors. Nonetheless, neutrophils possess at least three groups of enzymes that are thought to have the ability to degrade key components of the basement membrane in a plasma milieu; the serine proteinases, elastase, and cathepsin G $(20,21,51,52)$; the metalloproteinases, collagenase, and gelatinase (53-55); and the endoglycosidase, heparanase (22). 

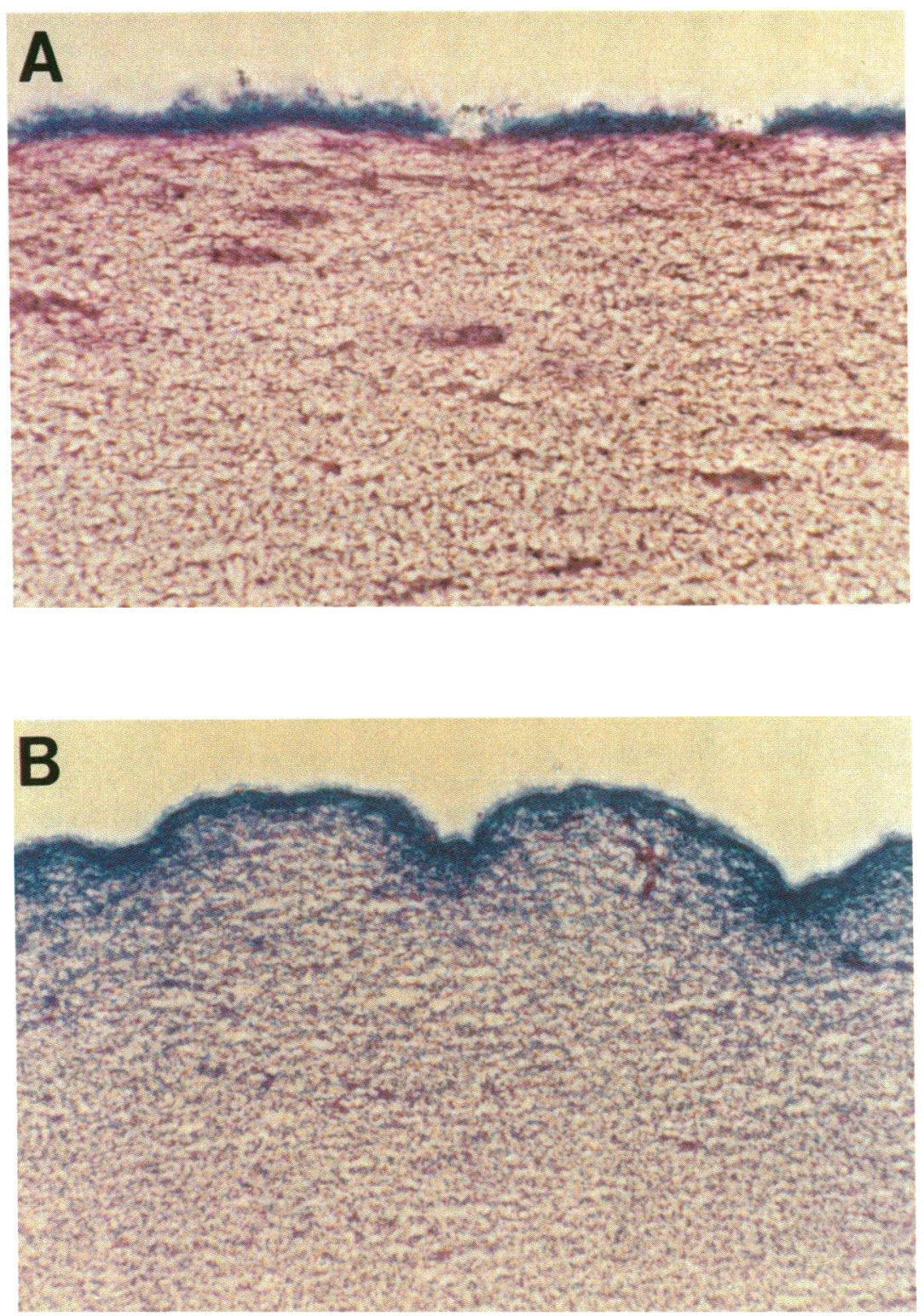

Figure 6. Impenetrability of a denuded basement membrane to a colloidal pigment. A 21-d-old vessel construct was denuded and overlaid with monastral blue as described. After a $10-\mathrm{h}$ incubation, the surface of the basement membrane was carefully washed and the samples prepared for microscopy. $(A)$ A light micrograph of a cross-section of a basement membrane that had been overlaid with the blue colloid. $(B)$ A light micrograph of a cross-section of a type I collagen matrix that had been overlaid with the colloid. The pigment has penetrated into the type I collagen meshwork. The micrographs are shown at $\times 400$.
To determine whether any of these enzymes could be implicated in diapedesis, neutrophils were incubated with selected inhibitors and the ability of the cells to disrupt the basement membrane and invade the vessel wall construct assessed.

In cell-free systems, neutrophil elastase or cathepsin G activity can be blocked by specific chloromethylketone inhibitors (56). However, chloromethylketones can react with plasma thiols, and the cathepsin $\mathrm{G}$ inhibitor is known to adversely effect neutrophil function (56). As an alternate approach, neutrophils were pretreated with the powerful and irreversible serine proteinase inhibitor, DFP. After a 1-h incubation period, an analysis of neutrophil lysates revealed that elastase and cathepsin $\mathrm{G}$ activities had been inhibited by $>99$ and $97 \%$, respectively $(n=5)$. Surprisingly, if the DFP-pretreated neutrophils were examined for their invasive potential, both basement membrane disruption and emigration proceeded in an unabated fashion (Table I). Although neutrophils possess a limited capacity to synthesize protein (57), the emigration of DFP-treated cells was unaffected by the presence of $10 \mu \mathrm{g} / \mathrm{ml}$ cycloheximide during the $1 \mathrm{~h}$ assay (data not shown).
Thus, neither elastase nor cathepsin $\mathrm{G}$ activity could be implicated in neutrophil extravasation in this system.

Unlike elastase and cathepsin G, synthetic inhibitors that could be directed against either the neutrophil collagenolytic metalloproteinases or heparanase are not currently available. However, the postulated ability of these enzymes to degrade the basement membrane in vivo is related, in part, to the fact that plasma contains only low concentrations of TIMP, an inhibitor able to block neutrophil metalloproteinase activities ${ }^{4}$ $(55,58,59)$, and plasma heparanase inhibitors have not been identified (22). Indeed, in other systems, the addition of recombinant TIMP or the endoglycosidase inhibitor, heparin, has been shown to prevent tumor cell invasion and neutrophil-mediated heparan sulfate degradation, respectively $(22$, $60)$. Thus, changes in basement membrane integrity and neutrophil diapedesis were examined in the presence of either high

4. At a concentration of $1 \mu \mathrm{g} / \mathrm{ml}$, recombinant TIMP inhibited all of the collagenase and gelatinase activity released by $10^{6}$ neutrophils triggered with phorbol myristate acetate (data not shown). 

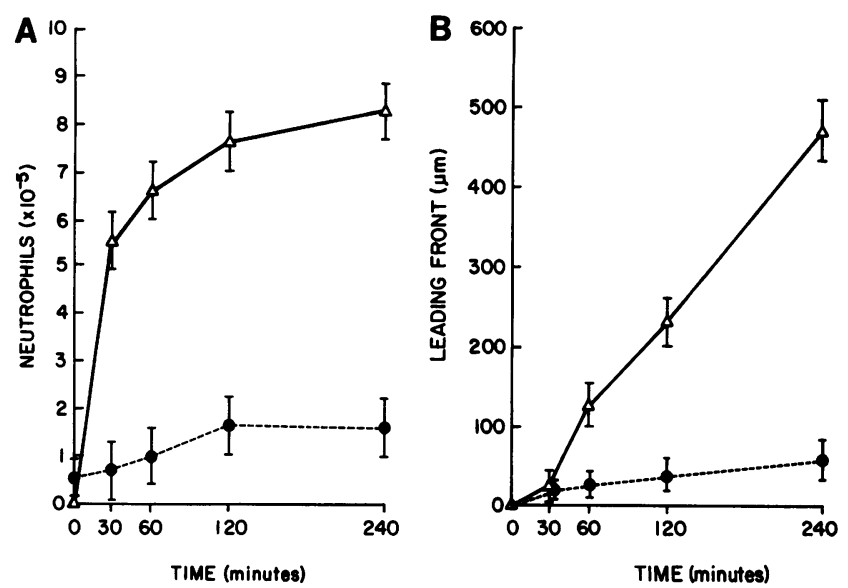

Figure 7. (A) Association of neutrophils with the vessel wall construct as a function of time. $1 \times 10^{6}$ neutrophils were added to the upper compartment with either heat-inactivated plasma $(\bullet)$ or zymosan activated plasma $(\Delta)$ in the lower compartment. At indicated time points the upper compartments were washed two times in the presence of EDTA as described and the number of nonadherent neutrophils determined. Results are expressed on the mean number of neutrophils that remained vessel wall-associated \pm 1 SEM of at least five experiments. $(B)$ Kinetics of neutrophil emigration through vessel wall constructs. $1 \times 10^{6}$ neutrophils were placed in the upper compartment and either heat-inactivated plasma (๑) or zymosan-activated plasma $(\Delta)$ in the lower compartments. The leading front was determined by phase microscopy at the indicated time points and expressed as the mean distance migrated \pm 1 SEM of five or more experiments. concentrations of recombinant TIMP or heparin. As shown in Table I, even if the plasma TIMP concentration was increased from its normal value of $\sim 0.5 \mu \mathrm{g} / \mathrm{ml} \mathrm{(59)}$ to 10 or even 20 $\mu \mathrm{g} / \mathrm{ml}$ (data not shown), neutrophils penetrated the basement membrane and migrated normally. Likewise, the addition of $10 \mu \mathrm{g} / \mathrm{ml}$ heparin (either isolated from porcine intestine or bovine lung) failed to exert any inhibitory effect on neutrophil invasion (Table I). Thus, neutrophil extravasation was resistant to high concentrations of both metalloproteinase and endoglycosidase inhibitors.

Given the fact that inhibitors directed against enzymes known to participate in basement membrane degradation failed to prevent diapedesis, a broad range of additional synthetic inhibitors were examined $(61,62)$. However, inhibitors of plasminogen activator (benzamidine, leupeptin), plasmin (aprotinin or $\epsilon$-aminocaproic acid), neutral metalloendoprotease (phosphoramidon), cysteine proteases (leupeptin), or aspartate proteases (pepstatin) did not interfere with either basement membrane disruption or neutrophil invasion (Table I). Thus, not only is neutrophil extravasation resistant to all plasma proteinase inhibitors, but also to a wide range of synthetic inhibitors directed against each of the major classes of proteases.

Reconstitution of basement membrane integrity. Thus far; the data suggest that basement membrane disruption is a physiologic consequence of neutrophil diapedesis. However, if the loss of matrix integrity reflects a regulated process, then mechanisms should exist that allow for the reconstitution of normal barrier function. To determine whether diapedesis-induced

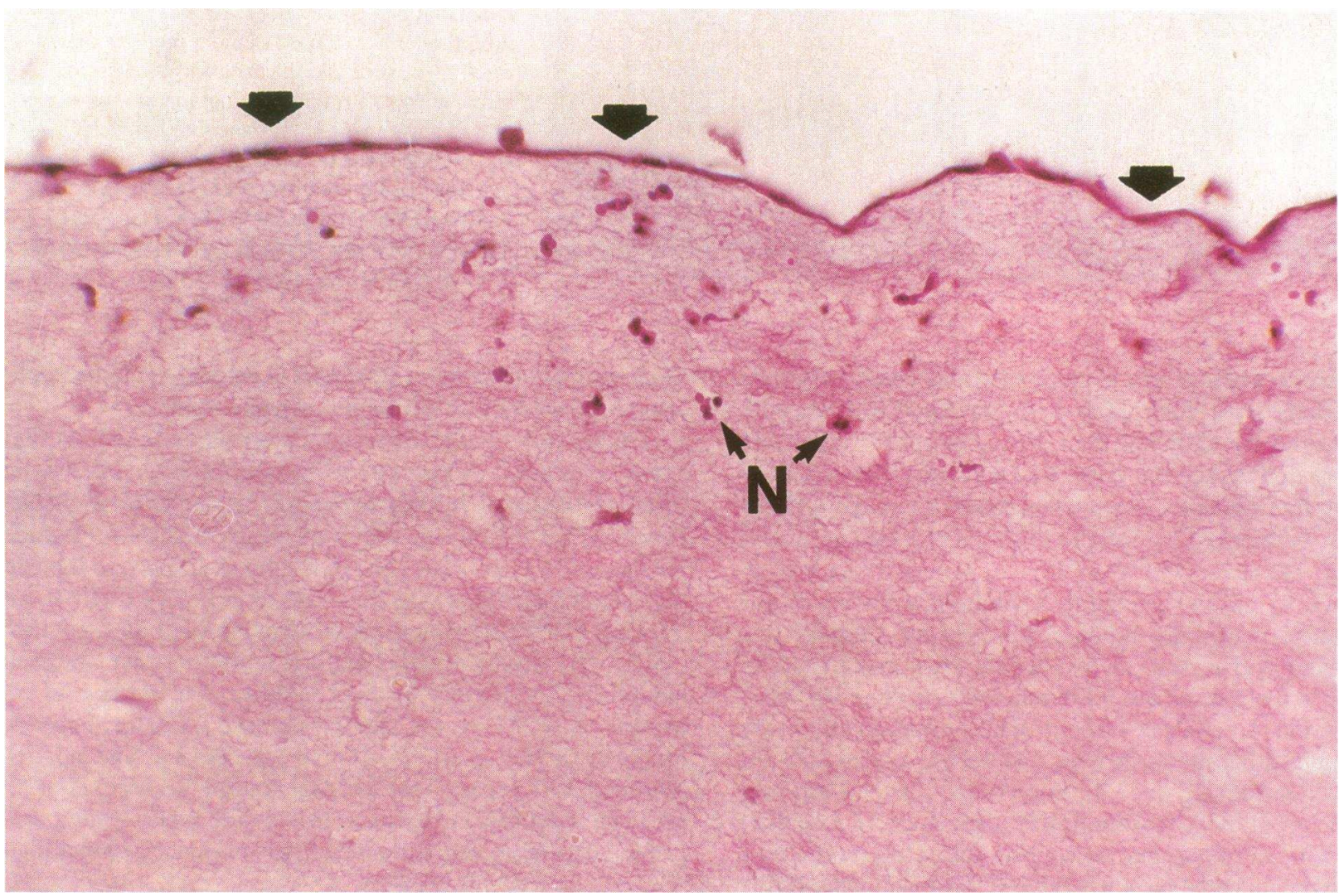

Figure 8. Penetration of the vessel wall construct by neutrophils. Vessel wall constructs were incubated with $10^{6}$ neutrophils in the upper compartment and zymosan-activated plasma in the lower compartment for $2 \mathrm{~h}$ at $37^{\circ} \mathrm{C}$. The sample was then processed for light microscopy as described. Infiltrating neutrophils are identified as $N$ and the endothelial cell layer with arrowheads. The micrographs are shown at $\times 100$. 

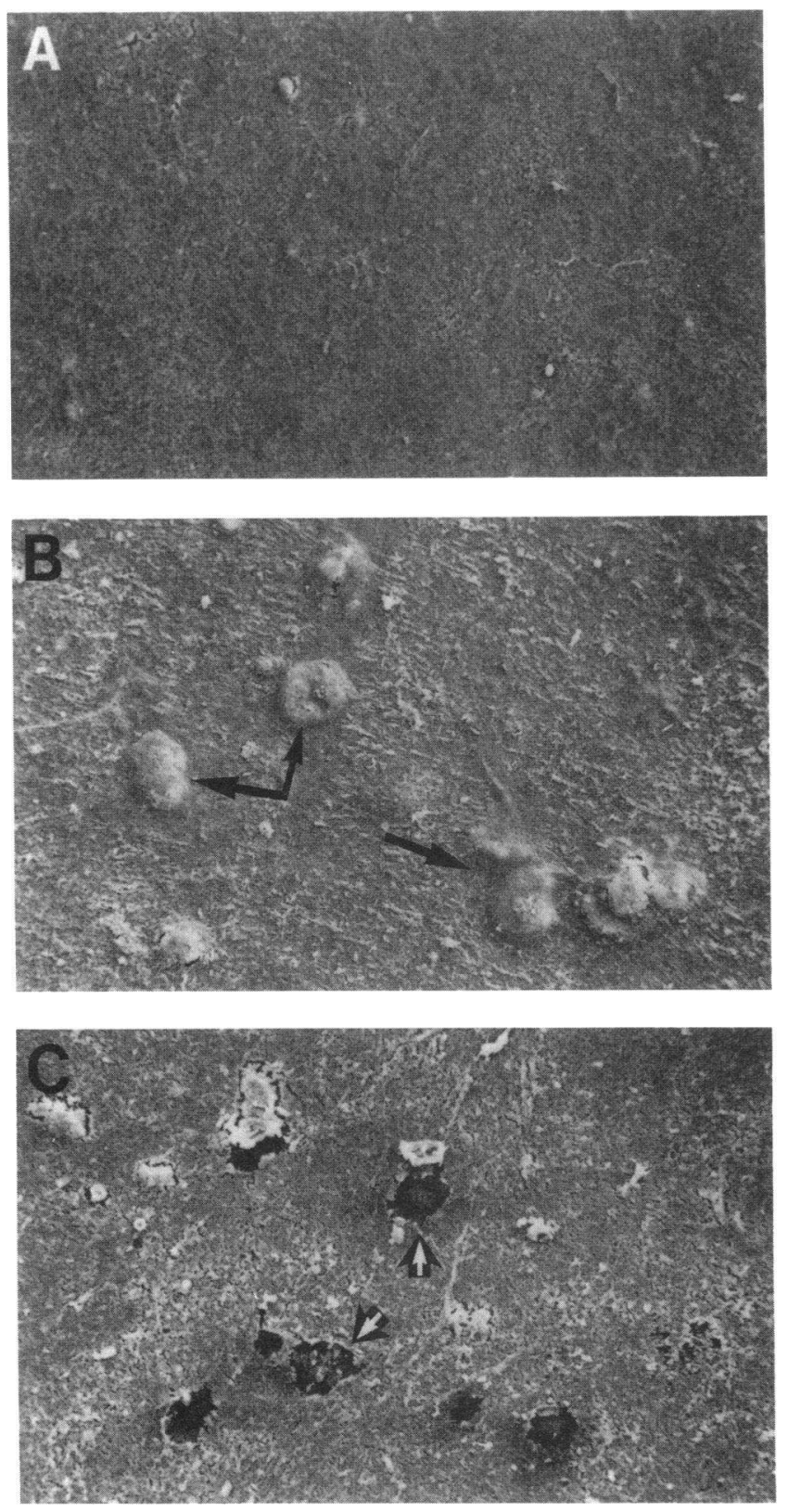

Figure 9. Scanning electron micrographs of denuded basement membranes recovered after neutrophil emigration. Vessel wall constructs were incubated with neutrophils $\left(1 \times 10^{6}\right)$ in the upper compartment and heat-inactivated or zymosan-activated plasma in the lower compartment for $1 \mathrm{~h}$. The endothelial cell monolayers were then lysed as described and the denuded basement membranes processed for electron microscopy. $(A)$ Micrograph of a basement membrane isolated from a vessel wall incubated with resting neutrophils. $(B)$ Basement membrane prepared from a transmigrated vessel wall showing numerous distortions of the matrix, presumably caused by the underlying neutrophils. Focal defects in the basement membrane cannot be discerned. (C) An anomalous, single preparation of a transmigrated vessel wall that revealed numerous well-demarcated holes. The micrographs are shown at $\times 625$.

basement membrane defects were repairable, vessel wall constructs were incubated with resting or emigrating neutrophils for increasing periods of time (ranging from 1 to $18 \mathrm{~h}$ ) before the monastral blue permeability of the denuded basement membranes was quantitated. As shown in Fig. 11, the ability of the transmigrated basement membranes to exclude the colloid was almost completely re-established within $4 \mathrm{~h}$. After an 18-h incubation, the barrier function of the traversed basement membranes was no different than controls (Fig. 11). As expected, resting neutrophils did not significantly alter the basement membrane's ability to exclude the colloid at any of the time points examined (Fig. 11). Thus, the basement membrane defects induced by extravasating neutrophils were only transiently expressed before the barrier was repaired. To determine whether active protein synthesis played a role in the repair process, experiments were repeated in the presence of cycloheximide. Transmigration proceeded normally in the presence of $10 \mu \mathrm{g} / \mathrm{ml}$ cycloheximide and endothelial cell morphology remained grossly unchanged for at least $18 \mathrm{~h}$ (data not shown). However, under these conditions, the basement membrane defects were not repaired and the basement membranes remained highly permeable to monastral blue throughout the 18-h incubation (Fig. 11). Treatment of the vessel wall constructs with cycloheximide alone had no effect on monastral blue permeability, and the ability of cycloheximide to inhibit matrix repair was reversed if the treated cultures were washed after $1 \mathrm{~h}$ of transmigration and then returned to fresh culture medium for an additional $17 \mathrm{~h}$ (data not shown). Finally, basement membrane repair was also prevented by allowing neutrophils to emigrate across vessel wall constructs in the presence of $10 \mu \mathrm{g} / \mathrm{ml}$ actinomycin $D$. In these experiments monastral blue permeabilities in transmigrated cultures that had been incubated with the inhibitor for 1 and $18 \mathrm{~h}$ were $113.4 \pm 4.5 \mu \mathrm{g}$ and $112.4 \pm 7.6 \mu \mathrm{g}$, respectively (mean $\pm 1 \mathrm{SEM} ; n$ =3). Actinomycin $D$ alone had no effect on colloid permeability or neutrophil migration (data not shown). Thus, the loss of basement membrane barrier function attendant with neutrophil emigration was reversible, but required both active protein and RNA synthesis.

\section{Discussion}

To examine the interaction between extravasating neutrophils and the subendothelial cell basement membrane in a physiologic setting, a homologous, in vitro construct of the venular vessel wall was developed. Although a number of in vitro systems have been described wherein endothelial cells are cultured on artificial porous supports, the endothelial cell monolayers have been reported to either contain large interendothelial cell gaps or to fail to display lateral membrane fusions (29). In addition, the cultured endothelial cells secrete a discontinuous, multilayered, and polymorphous matrix whose barrier function would be predictably compromised $(28,29)$. In the face of these shortcomings, the amniotic membrane has recently been suggested as a more physiologic substratum for the culture of endothelial cells $(34,63)$. However, in contrast to earlier claims regarding the utility of this model for the study of neutrophil transmigration, more recent reports have indicated that both the amniotic basement membrane and the zona reticularis act as almost impenetrable barriers to neutrophil invasion in vitro as well as in vivo $(27,64)$.

In light of these difficulties, we sought to design an in vitro system in which cultured endothelial cell monolayers would form a vessel wall mimic with more physiologic characteristics. The decision to use umbilical vein rather than microvascular endothelial cells in a model system for studying neutro- 


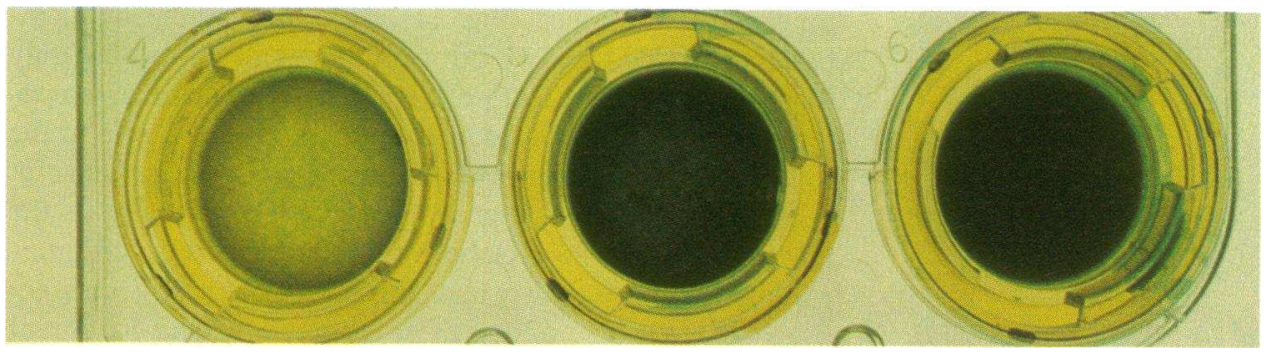

Figure 10. Loss of basement membrane barrier function after neutrophil transmigration. Vessel wall constructs were incubated with $1 \times 10^{6}$ neutrophils in the upper compartment and either heat-inactivated or zymosan-activated plasma in the lower compartment for $1 \mathrm{~h}$. The samples were then washed and the monolayers were detergent lysed and then overlaid with monastral blue as described. After a 10-h incubation the samples were vigorously washed and photographed. From left to right, the first well is a denuded vessel wall construct that had been incubated with resting neutrophils. Basement membrane barrier function remained intact and the colloid failed to penetrate into the type I collagen layer. The small amount of detectable pigment is solely associated with the apical surface of the denuded basement membrane (see Fig. $6 \mathrm{~A}$ ). The second well shows a denuded vessel wall from a transmigrated culture that exhibited a marked decrease in the basement membrane's ability to exclude the colloid. Large amounts of the blue pigment can be seen associated with the matrix. Cross-sections of the vessel wall construct demonstrated that the colloid penetrated beneath the basement membrane and that the colloid was not surface associated (not shown). In the third well a naked matrix of type I collagen was treated as described above, overlaid with pigment, washed, and photographed.

phil interactions with the postcapillary venule was based on the facts that $(a)$ the precise vascular source of microvascular endothelial cells cannot be accurately ascertained, and $(b)$ cultured umbilical vein endothelial cells have recently been shown to respond to a number of inflammatory mediators in a manner similar, if not identical, to that observed for the postcapillary venule (65). A type I collagen gel was selected as the substratum of choice because it is a primary collagenous component of the interstitial matrix (12), provides an excellent surface for endothelial cell growth (66), and is penetrable by migrating neutrophils (67-69). As demonstrated, after a 21-23-d culture period, confluent endothelial cell monolayers displayed a number of structural and functional characteristics that have been described for small venules in vivo. In contrast to other models, tight junctions were routinely visible, interendothelial cell gaps were not detected, ${ }^{5}$ and the basement membrane was single-layered and appeared continuous by morphologic analysis. An additional assurance of matrix integrity was sought by determining the barrier function of the synthesized basement membrane. In vivo, colloids (either carbon black or monastral blue particles, $\sim 300-500 \AA \AA)$ injected into the vascular bed of a normal animal do not cross vessel walls because the particles are unable to penetrate between interendothelial cell junctions $(3,42,50)$. However, after the application of a histamine-type inflammatory mediator, inter-

5. In over 500 junctions examined, no gaps were found. Although we attempted to measure transendothelial electrical resistance in our vessel wall construct, the high resistance of the type I collagen-coated filters alone precluded such measurements. endothelial cell gaps appear in nearby postcapillary venules and the circulating colloid rapidly penetrates to, but not through, the exposed basement membrane $(3,42,50)$. Given an in vivo index of basement membrane integrity, we demonstrated that basement membranes synthesized in vitro likewise prohibited the efflux of monastral blue. Taken together, these data suggest that the umbilical vein endothelial cell-type I collagen construct is a powerful tool for analyzing venule function in a physiologic setting.

In order for extravasating neutrophils to traverse the subendothelial basement membrane, it has been postulated that the cells (as well as other leukocyte populations and metastatic cells; e.g., see reference 70) actively digest the subendothelial matrix to gain access to the interstitium (1). However, despite heightened interest in the mechanisms that underlie vessel wall transmigration, it is surprising to find that the fate of the traversed basement membrane has never been resolved. Although it is often assumed that basement membrane disruption must be a necessary consequence of cellular emigration, there has been little in the way of direct evidence to support this contention. To the contrary, transmission electron micrographs of vessel walls that had been traversed by neutrophils in vivo have not revealed consistent changes in the appearance of the basement membranes (15-18). Similarly, even in our in vitro system, scanning electron microscopy of denuded basement membranes prepared from transmigrated cultures failed to identify focal matrix defects. Indeed, based on the early observation that erythrocytes could assume deformed shapes that allowed them to traverse morphologically intact basement membranes in vivo, Majno and Palade suggested that matrix structure might bear closer resemblance to a penetrable sieve 
Table I. Neutrophil Emigration and Basement Membrane Perforation in the Presence of Enzyme Inhibitors

\begin{tabular}{lcccc}
\hline \multicolumn{1}{c}{ Additive } & $\begin{array}{c}\text { Vessel } \\
\text { wall-associated } \\
\text { neutrophils* }\end{array}$ & $\begin{array}{c}\text { Leading } \\
\text { front }^{\ddagger}\end{array}$ & $\begin{array}{c}\text { Colloid } \\
\text { permeability }\end{array}$ \\
\hline & $\times 10^{-3}$ & $\mu m$ & $\mu g$ \\
Neutrophils" & $651 \pm 4$ & $127 \pm 5$ & $94.5 \pm 12.5$ \\
Neutrophils + DFP' & $658 \pm 9$ & $133 \pm 5$ & $109.8 \pm 16.4$ \\
Neutrophils + TIMP & $664 \pm 6$ & $129 \pm 7$ & $125.1 \pm 15.5$ \\
Neutrophils + heparin & $647 \pm 14$ & $130 \pm 2$ & $121.7 \pm 27.8$ \\
Neutrophils + benzamidine & $671 \pm 11$ & $117 \pm 7$ & $84.0 \pm 12.9$ \\
Neutrophils + aprotinin & $666 \pm 16$ & $120 \pm 6$ & $86.0 \pm 14.8$ \\
Neutrophils + $\epsilon$-aminocaproic acid & $661 \pm 23$ & $123 \pm 9$ & $82.2 \pm 11.7$ \\
Neutrophils + leupeptin & $651 \pm 14$ & $132 \pm 3$ & $79.4 \pm 5.7$ \\
Neutrophils + pepstatin & $669 \pm 23$ & $117 \pm 5$ & $87.5 \pm 9.5$ \\
Neutrophils + phosphoramidon & $693 \pm 6$ & $120 \pm 6$ & $94.7 \pm 9.5$ \\
& & &
\end{tabular}

* Results are expressed as the mean number of vessel wall-associated neutrophils \pm 1 SEM $(n=3)$.

$\ddagger$ Results are expressed as the mean distance migrated \pm 1 SEM $(n=3)$. ${ }^{8}$ Results are expressed as the amount of colloid (mean \pm 1 SEM; $n=3$ ) that penetrated a denuded basement membrane during a $10-\mathrm{h}$ incubation at $4^{\circ} \mathrm{C}$ as described in Methods.

" $10^{6}$ neutrophils were placed in the upper chamber with $20 \%$ zymosan-activated plasma in the lower chamber and incubated for $1 \mathrm{~h}$ in the absence or presence of $10 \mu \mathrm{g} / \mathrm{ml} \mathrm{TIMP,} 10 \mu \mathrm{g} / \mathrm{ml}$ heparin, $2 \mathrm{mM}$ benzamidine, $100 \mathrm{U} / \mathrm{ml}$ aprotinin, $10 \mathrm{mM} \epsilon$-aminocaproic acid, 0.5 $\mathrm{mM}$ leupeptin, $0.3 \mathrm{mM}$ pepstatin, and $1 \mu \mathrm{M}$ phosphoramidon, respectively. Control values (i.e., neutrophils in the upper chamber with heat-inactivated plasma in the lower chamber) were $43 \times 10^{3}$ neutrophils $(n=2), 23 \mu \mathrm{m}(n=2)$, and $4.8 \mu \mathrm{g}$ colloid $(n=2)$ for the number of vessel wall-associated neutrophils, leading front, and monastral blue permeability, respectively.

'DFP-treated neutrophils were obtained by pretreating the cells with $5 \mathrm{mM}$ DFP for $1 \mathrm{~h}$ as described in Methods.

rather than an impenetrable barrier, and that matrix disruption may not be required for transmigration (71). However, in contrast to the absence of morphologic changes, we have found that the colloid permeability of the basement mem-

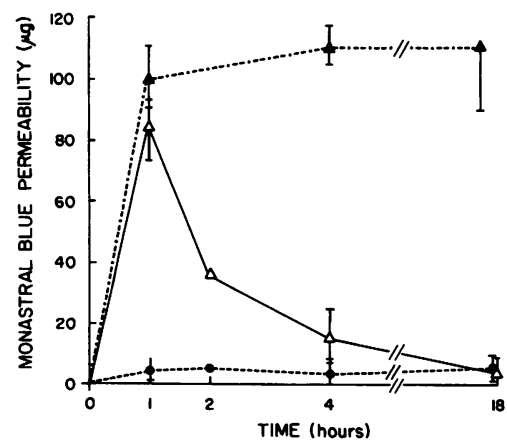

Figure 11. Alterations in the barrier function of the subendothelial basement membrane as a function of time. Vessel wall constructs were incubated with $1 \times 10^{6}$ in the upper compartment and heat-inactivated plasma in the lower compartment (๑), or with zymosan-activated plasma in the

lower compartment $(\bullet)$, or with zymosan-activated plasma in the lower compartment in the absence $(\Delta)$ or presence $(\Delta)$ of $10 \mu \mathrm{g}$ of cycloheximide. Results are expressed as the mean $\mu \mathrm{g}$ of pigment that penetrated the basement membrane \pm 1 SEM of seven experiments at the 1-, 4-, and 18-h timepoints and the mean of two experiments at the 2-h timepoint. branes was dramatically increased after a $1-h$ incubation with extravasating neutrophils. Further studies have revealed that even larger increases in monastral blue permeability could be detected before the cells actually crossed this barrier; i.e., after a 0.5-h incubation with migrating neutrophils the matrix leaked 121.9 $\pm 3.0 \mu \mathrm{g}$ of colloid (mean \pm 1 SEM; $n=3$ ). Because the disruption of basement membrane integrity occurred at a point in time where the majority of neutrophils were still in contact with the apical face of the matrix, emigrating neutrophils clearly initiated the alteration of matrix structure coincident with, and not after, penetration. Given this result and the fact that even a mechanically denuded vessel wall will retard the efflux of large macromolecules and cells from the vascular bed in vivo $(3,72,73)$, it seems reasonable to assume that basement membrane disruption is a necessary prerequisite for neutrophil emigration. Since these results predict that the basement membrane of venules surrounding an inflamed site are undergoing active perforation, it is tempting to speculate that the leakage of lipoproteins, fibrinogen, and erythrocytes into inflamed sites in vivo reflects the imperfect masking of matrix defects by the overlying endothelium $(72,73)$. Finally, it should be stressed that conclusions regarding the status of the subendothelial basement membrane are quite distinct from recent reports demonstrating the ability of migrating neutrophils to alter transcellular electrical resistance $(74,75)$. The electrical measurements only reflect the "tightness" of intercellular occluding junctions to small ions, and changes in electrical resistance occur independently of alterations in basement membrane integrity (13). Only if the structure of the basement membrane is directly compromised can large intravascular constituents gain free access to the interstitium (3, 72, 73).

Given the fact that emigrating neutrophils disrupted basement membrane integrity, we attempted to identify the enzymes that participated in vessel wall invasion. Neutrophils are known to contain a large number of enzymatic activities that arm the cell with the ability to degrade connective tissueassociated proteins, glycoproteins, and proteoglycans. Although these enzymes are usually implicated in pathologic tissue destruction, increased interest has focused on the possibility that these same enzymes play a role in promoting the cell's ability to traverse connective tissue barriers (20-22, 53-55). A role for neutrophil elastase has been particularly attractive because the enzyme is released from chemotaxintriggered cells, can mediate proteolysis in the presence of plasma proteinase inhibitors, and is able to degrade a number of the major structural and functional components of the basement membrane, including type IV collagen and plasminogen activator inhibitor $(10,21,51,52,76)$. Nonetheless, we were surprised to find that neutrophils pretreated with DFP, a potent serine proteinase inhibitor that drastically depressed both the cell's elastase as well as cathepsin G activities, successfully permeabilized the basement membrane and migrated normally. Although DFP would be expected to inhibit all active serine proteinases, more recent studies have demonstrated that neutrophils can also express latent plasminogen activator activity and in turn, have the ability to generate plasmin $(77,78)$. Latent plasminogen activator is not affected by DFP (77), but a range of potent, small molecular weight plasminogen activator and plasmin inhibitors all failed to impair diapedesis. Similarly, Furie et al. concluded that neither plasminogen activator nor plasmin played a role in neutrophil 
transmigration across a bovine endothelial cell monolayer cultured on a human amniotic membrane (27). Thus, no direct role for elastase, cathepsin $G$, plasminogen activator, or plasmin could be established for either neutrophil diapedesis, basement membrane disruption, or the cell's ability to traverse the underlying interstitial collagen matrix.

In addition to the serine proteinases, the neutrophil metalloproteinases, collagenase, and gelatinase, as well as the endoglycosidase, heparanase, have also been suggested to play roles in neutrophil invasion (22, 53-55). Gelatinase is thought to have the ability to degrade type IV collagen, and heparanase activity has been shown to correlate with the metastatic potential of tumor cells $(22,54)$. In addition, these enzymes (especially gelatinase and heparanase) have attracted particular attention both because they can be easily mobilized from neutrophils and, once released, the ability of plasma inhibitors to regulate their activities is unclear $(22,53)$. However, neither the addition of recombinant TIMP nor exogenous heparin exerted any inhibitory effect in our model. Although the targeted enzymes might have acted in a sequestered environment that was inaccessible to fluid phase inhibitors, it should be noted that the concentrations of TIMP used in this study are two to four times higher than those reported to prevent metastatic tumor cells from invading a denuded amniotic membrane (60), and that heparin has been reported to block neutrophil-mediated degradation of heparan sulfate localized to the subendothelial extracellular matrix (22). Taken together, our inhibitor studies suggest that neutrophils either possess additional, but uncharacterized, proteolytic activities that allow them to disrupt and penetrate the basement membrane or use enzymes that are remarkably resistant to combinations of plasma-borne and exogenous, synthetic inhibitors. Along these lines, we have recently found that neutrophils can degrade a wide range of matrix-associated proteins in a plasmarich milieu via an unusual proteolytic process that is resistant to a range of synthetic serine-, cysteine-, aspartate-, and metallo-proteinase inhibitors (Rice, W. G., and S. J. Weiss, manuscript in preparation). Studies are underway to determine whether emigrating neutrophils might similarly use novel proteolytic activities to disrupt the basement membrane.

In spite of the stress placed on the neutrophil as the sole active participant in the penetration of the basement membrane, a possible role for the endothelial cells themselves should be considered. Endothelial cells not only can synthesize serine and metallo-proteinases that are able to degrade basement components (79-82), but the cells are also able to rapidly reorganize basement membrane structure in a manner that alters biologic reactivity (83). In an attempt to more directly address the role of endothelial cells in neutrophil emigration, we have recently examined the ability of denuded basement membranes to support chemotaxis (unpublished observation). In this system, neutrophils exposed to a chemotactic gradient of zymosan-activated plasma were able to adhere and spread on the basement membrane, but failed to penetrate the matrix and move into the type I collagen stroma. Whether these results indicate that endothelial cells directly participate in emigration by "preparing" their basement membrane for invasion or by providing required signals to the extravasating neutrophils is unknown (84). Nonetheless, endothelial cells appear to act as a critical component in neutrophil emigration and their role merits further consideration.

Regardless of the relative roles of the extravasating neutro- phil and endothelial cell monolayer in the disruption of the basement membrane, the defects were repairable. Because the barrier function of the basement membrane was rapidly reconstituted after a continued incubation period, we considered the possibility that the neutrophil might have mechanically forced its way though a gel-like barrier that spontaneously reannealed. Indeed, in data not shown, neutrophil transmigration was not associated with the release of basement membrane fragments from radiolabeled cultures or by marked changes in the distribution of proteins extracted from the matrix after analysis by SDS-PAGE (unpublished observations). However, even in the absence of biochemical indices of matrix disruption, the lateral organization of the type IV collagen network (85) and the known resistance of the basement membrane to mechanical damage $(2-4,47)$ would suggest that this barrier is not easily penetrated. More directly, the fact that barrier function could not be re-established if transmigration proceeded in the presence of cycloheximide or actinomycin D strongly suggests that structural damage had occurred and that active protein and RNA synthesis were necessary for the repair of the matrix defects. Although neutrophils themselves are able to synthesize at least one connective tissue protein (i.e., fibronectin; reference 57), the fact that few, if any, leukocytes remain associated with the basement membrane during the period of repair render this possibility unlikely. Additional studies are underway in our laboratory to identify the structural composition of the matrix defects and the identity of the products synthesized by the transmigrated endothelial cells.

In summary, we have constructed a model of the venular vessel wall and demonstrated that transmigrating neutrophils participate in the transient disruption of the barrier function of the subendothelial basement membrane. As in all in vitro systems, a final question arises with regard to whether neutrophils mediate similar changes in basement membrane structure in vivo. Interestingly, an almost forgotten study published 25 years ago demonstrated that the normal in vivo impenetrability of the basement membrane to colloid efflux could be compromised if neutrophils were triggered to extravasate across venules whose endothelia were simultaneously retracted by a local injection of histamine (86). These findings are entirely consistent with the conclusion that neutrophils actively disrupt and alter the subendothelial basement membrane both in vitro and in vivo. The identification of the processes that regulate the disruption and repair of the subendothelial basement membrane during neutrophil emigration should provide new insights into the regulation of the inflammatory response. Furthermore, the possibility that the mechanisms used by the neutrophil to traverse the vessel wall might serve as a prototype for the processes used by other normal and abnormal emigrating cell populations (e.g., lymphocytes, endothelial cells, and tumor cells) deserves careful consideration.

\section{Acknowledgments}

We thank Dr. D. MacCallum and Dr. J. Lillie for helpful discussions with regard to the morphologic studies, B. Donohoe, L. Baumgarten, and the staff of the Cell Biology Laboratories at The University of Michigan for technical assistance with microscopy, and S. Regiani for technical support.

This work was supported by National Institutes of Health grants HL-28024 and Al-23876. Dr. Huber was supported by a grant from the Swiss National Science Foundation. 


\section{References}

1. Harlan, J. M. 1985. Leukocyte-endothelial interactions. Blood. 65:513-525.

2. Vracko, R. 1974. Basal lamina scaffold-anatomy and significance for maintenance of orderly tissue structure. Am. J. Pathol. 77:314-346.

3. Majno, G. 1964. Ultrastructure of the vascular membrane. In Handbook of Physiology, Vol. III. W. Hamilton, editor. Williams \& Wilkins Co., Baltimore. 2293-2375.

4. Ross, M. H., and L. Grant. 1968. On the structural integrity of basement membrane. Exp. Cell Res. 50:277-285.

5. Gospodarowicz, D., and C. Ill. 1980. Extracellular matrix and control of proliferation of vascular endothelial cells. J. Clin. Invest. 65:1351-1364.

6. Madri, J. A., and B. M. Pratt. 1986. Endothelial cell-matrix interactions: in vitro models of angiogenesis. J. Histochem. Cytochem. 34:85-91.

7. Vlodavsky, I., J. Folkman, R. Sullivan, R. Fridman, R. IshaiMichaeli, J. Sasse, and M. Klagsbrun. 1987. Endothelial cell-derived basic fibroblast growth factor: synthesis and deposition into subendothelial extracellular matrix. Proc. Natl. Acad. Sci. USA. 84:2292-2296.

8. Knudsen, B. S., R. L. Silverstein, L. L. K. Leung, P. C. Harpel, and R. L. Nachman. 1986. Binding of plasminogen to extracellular matrix. J. Biol. Chem. 261:10765-10771.

9. Bar-Ner, M., M. Mayer, V. Schirrmacher, and I. Vlodavsky. 1986. Involvement of both heparanase and plasminogen activator in lymphoma cell-mediated degradation of heparan sulfate in the subendothelial extracellular matrix. J. Cell. Physiol. 128:299-306.

10. Levin, E. G., and L. Santell. 1987. Association of a plasminogen activator inhibitor (PAI-1) with the growth substratum and membrane of human endothelial cells. J. Cell Biol. 105:2543-2549.

11. Wagner, D. D., M. Urban-Pickering, and V. J. Marder. 1984. von Willebrand protein binds to extracellular matrices independently of collagen. Proc. Natl. Acad. Sci. USA. 81:471-475.

12. Hay, E. D. 1982. Cell Biology of Extracellular Matrix. Plenum Publishing Corp., New York. 417.

13. Simionescu, N. 1983. Cellular aspects of transcapillary exchange. Physiol. Rev. 63:1536-1579.

14. Williamson, J. R., and J. W. Grisham. 1961. Electron microscopy of leukocytic margination and emigration in acute inflammation in dog pancreas. Am. J. Pathol. 39:239-256.

15. Hurley, J. V., and N. Xeros. 1961. Electron microscopic observations on the emigration of leucocytes. Aust. J. Exp. Biol. Med. Sci. 39:609-624.

16. Hurley, J. V. 1963. An electron microscopic study of leukocytic emigration and vascular permeability in rat skin. Aust. J. Exp. Biol. Med. Sci. 41:171-186.

17. Marchesi, V. T. 1964. Some electron microscopic observations on interactions between leukocytes, platelets, and endothelial cells in acute inflammation. Ann. NY Acad. Sci. 116:774-788.

18. Shaw, J. O. 1980. Leukocytes in chemotactic-fragment-induced lung inflammation. Am. J. Pathol. 101:283-302.

19. Fehr, J., R. Moser, D. Leppert, and P. Groscurth. 1985. Antiadhesive properties of biological surfaces are protective against stimulated granulocytes. J. Clin. Invest. 76:535-542.

20. Weiss, S. J., and Regiani, S. 1984. Neutrophils degrade subendothelial matrices in the presence of alpha-1-proteinase inhibitor. $J$. Clin. Invest. 73:1297-1303.

21. Weiss, S. J., J. T. Curnutte, and S. Regiani. 1986. Neutrophilmediated solubilization of the subendothelial matrix: Oxidative and nonoxidative mechanisms of proteolysis used by normal and chronic granulomatous disease phagocytes. J. Immunol. 136:636-641.

22. Matzner, Y., M. Bar-Ner, J. Yahalom, R. Ishai-Michaeli, Z. Fuks, and I. Vlodavsky. 1985. Degradation of heparan sulfate in the subendothelial extracellular matrix by a readily released heparanase from human neutrophils. J. Clin. Invest. 76:1306-1313.

23. Beesley, J. E., J. D. Pearson, A. Hutchings, J. S. Carleton, and
J. L. Gordon. 1979. Granulocyte migration through endothelium in culture. J. Cell Sci. 38:237-248.

24. Taylor, R. F., T. H. Price, S. M. Schwartz, and D. C. Dale. 1981. Neutrophil-endothelial cell interactions on endothelial monolayers grown on micropore filters. J. Clin. Invest. 67:584-587.

25. Harlan, J. M., B. R. Schwartz, M. A. Reidy, S. M. Schwartz, H. D. Ochs, and L. A. Harker. 1985. Activated neutrophils disrupt endothelial cell monolayer integrity by an oxygen-radical independent mechanism. Lab. Invest. 52:141-150.

26. Doukas, J., D. Shepro, and H. B. Hechtman. 1987. Vasoactive amines directly modify endothelial cells to affect polymorphonuclear leukocyte diapedesis in vitro. Blood. 69:1563-1569.

27. Furie, M. B., B. L. Naprstek, and S. C. Silverstein. 1987. Migration of neutrophils across monolayers of cultured microvascular endothelial cells. J. Cell Sci. 88:161-175.

28. Kramer, R. H., K. G. Bensch, P. M. Davison, and M. A. Karasek. 1984. Basal lamina formation by cultured microvascular endothelial cells. J. Cell Biol. 99:692-698.

29. Albelda, S. M., P. M. Sampson, F. R. Haselton, J. M. McNiff, S. N. Mueller, S. K. Williams, A. P. Fishman, and E. M. Levine. 1988. Permeability characteristics of cultured endothelial cell monolayers. $J$. Appl. Physiol. 64:308-322.

30. Gimbrone, M. A. 1976. Culture of vascular endothelium. In Progress in Hemostasis and Thrombosis, Vol. III. T. H. Spaet, editor. Grune and Stratton, New York, 1-28.

31. Bornstein, M. B. 1958. Reconstituted rat-tail collagen used as substrate for tissue cultures on coverslips in Maximow slides and roller tubes. Lab. Invest. 7:134-137.

32. Ross, R., A. Vogel, P. Davies, E. Raines, B. Kariya, M. J. Rivest, C. Gustafson, and J. Glomset. 1979. Hormones and cell culture. In Cold Spring Harbor Conference on Cell Proliferation. G. Sato and R. Ross, editors. Cold Spring Harbor Laboratory, Cold Spring Harbor, NY. 3-15.

33. Lohr, K. M., and R. Snyderman. 1982. Amphotericin B alters the affinity and functional activity of the oligopeptide chemotactic factor receptor on human polymorphonuclear leukocytes. J. Immunol. 129:1594-1599.

34. Furie, M. B., E. B. Cramer, B. L. Naprstek, and S. C. Silverstein. 1984. Cultured endothelial cell monolayers that restrict the transendothelial passage of macromolecules and electrical current. $J$. Cell Biol. 98:1033-1041.

35. Lillie, J. H., D. K. MacCallum, and A. Jepsen. 1982. The behavior of subcultivated stratified squamous epithelial cells on reconstituted extracellular matrices: initial interactions. Eur. J. Cell Biol. 29:50-60.

36. Luft, J. H. 1966. Fine structure of capillary and endocapillary layer as revealed by ruthenium red. Fed. Proc. 25:1773-1783.

37. Simionescu, N., and M. Simionescu. 1976. Galloylglucoses of low molecular weight as mordant in electron microscopy. J. Cell Biol. 70:608-621.

38. Pauli, B. U., R. S. Weinstein, L. W. Soble, and J. Alroy. 1977. Freeze-fracture of monolayer cultures. J. Cell Biol. 72:763-769.

39. Nation, J. L. 1983. A new method using hexamethyldisilazane for preparation of soft insect tissues for scanning electron microscopy. Stain Technol. 58:347-351.

40. Kramer, R. H., G. M. Fuh, K. G. Bensch, and M. A. Karasek. 1985. Synthesis of extracellular matrix glycoproteins by cultured microvascular endothelial cells isolated from the dermis of neonatal and adult skin. J. Cell. Physiol. 123:1-9.

41. Kramer, R. H., G. M. Fuh, and M. A. Karasek. 1985. Type IV collagen synthesis by cultured human microvascular endothelial cells and its deposition into the subendothelial basement membrane. Biochemistry 24:7423-7430.

42. Joris, I., U. DeGirolami, K. Wortham, and G. Majno. 1982. Vascular labelling with Monastral blue B. Stain Technol. 57:177-183.

43. Martinez-Palomo, A., I. Meza, G. Beaty, and M. Cereijido. 1980. Experimental modulation of occluding junctions in a cultured transporting epithelium. J. Cell Biol. 87:736-745. 
44. Ossanna, P. J., S. T. Test, N. R. Matheson, S. Regiani, and S. J. Weiss. 1986. Oxidative regulation of neutrophil elastase-alpha-1-proteinase inhibitor interactions. J. Clin. Invest. 77:1939-1951.

45. Perez, H. D., D. E. Chenoweth, and I. M. Goldstein. 1986. Attachment of human C5a des arg to its cochemotaxin is required for maximum expression of chemotactic activity. J. Clin. Invest. 78:1589-1595.

46. Zigmond, S. H., and J. G. Hirsch. 1973. Leukocyte locomotion and chemotaxis. New methods for evaluation and demonstration of a cell-derived chemotactic factor. J. Exp. Med. 137:387-410.

47. Simionescu, M., and N. Simionescu. 1984. Ultrastructure of the microvascular wall: functional correlations. In Handbook of Physiology, Vol. IV. E. M. Renkin, and C. C. Michel, editors. Williams \& Wilkins Co., Baltimore. 41-101.

48. Canfield, A. E., A. Schor, S. Schor, and M. Grant. 1986. The biosynthesis of extracellular-matrix components by bovine retinal endothelial cells displaying distinctive morphological phenotypes. Biochem. J. 235:375-383.

49. Gospodarowicz, D., G. Greenburg, J. M. Foidart, and N. Savion. 1981. The production and localization of laminin in cultured vascular and corneal endothelial cells. J. Cell. Physiol. 107:171-183.

50. Cotran, R. S., E. R. Suter, and G. Majno. 1967. The use of colloidal carbon as a tracer for vascular injury. Vasc. Dis. 4:107-127.

51. Weitz, J. I., A. J. Huang, S. L. Landman, S. C. Nicholson, and S. C. Silverstein. 1987: Elastase-mediated fibrinogenolysis by chemoattractant-stimulated neutrophils occurs in the presence of physiologic concentrations of antiproteinases. J. Exp. Med. 166:1836-1850.

52. Campbell, E. J., and M. A. Campbell. 1988. Pericellular proteolysis by neutrophils in the presence of proteinase inhibitors: effects of substrate opsonization. J. Cell. Biol. 106:667-676.

53. Weiss, S. J., and G. J. Peppin. 1986. Collagenolytic metalloenzymes of the human neutrophil: characteristics, regulation and potential function in vivo. Biochem. Pharmacol. 35:3189-3197.

54. Shah, S. V., W. H. Baricos, and A. Basci. 1987. Degradation of human glomerular basement membrane by stimulated neutrophils. $J$. Clin. Invest. 79:25-31.

55. Murphy, G., J. J. Reynolds, U. Bretz, and M. Baggiolini. 1982. Partial purification of collagenase and gelatinase from human polymorphonuclear leucocytes. Biochem. J. 203:209-221.

56. Sibille, Y., W. W. Merril, J. A. Cooper, L. Polomski, and J. B. Gee. 1984. Effects of a series of chloromethyl ketone protease inhibitors on superoxide release and the glutathione system in human polymorphonuclear leukocytes and alveolar macrophages. Am. $R e v$. $R e-$ spir. Dis. 130:110-114.

57. La Fleur, M., A. D. Beaulieu, C. Kreis, and P. Poubelle. 1987. Fibronectin gene expression in polymorphonuclear leukocytes. J. Biol. Chem. 262:2111-2115.

58. Desrochers, P. E., and S. J. Weiss. 1988. Proteolytic inactivation of alpha-1-proteinase inhibitor by a neutrophil metalloproteinase. J. Clin. Invest. 81:1646-1650.

59. Cooper, T. W., A. Z. Eisen, G. P. Stricklin, and H. G. Welgus. 1985. Platelet-derived collagenase inhibitor: characterization and subcellular localization. Proc. Natl. Acad. Sci. USA. 82:2779-2783.

60. Mignatti, P., E. Robbins, and D. B. Rifkin. 1986. Tumor invasion through the human amniotic membrane: requirement for a proteinase cascade. Cell. 47:487-498.

61. Chen, J.-M., and W.-T. Chen. 1987. Fibronectin-degrading proteases from the membranes of transformed cells. Cell. 48:193-203.

62. Quigley, J. P. 1979. Phorbol ester-induced morphological changes in transformed chick fibroblasts: evidence for direct catalytic involvement of plasminogen activator. Cell. 17:131-141.

63. Migliorisi, G., E. Folkes, N. Pawlowski, and E. B. Cramer. 1987. In vitro studies of human monocyte migration across endothelium in response to leukotriene $\mathrm{B}_{4}$ and f-Met-Leu-Phe. Am. J. Pathol. 127:157-167.

64. Azzarelli, B., and J. Lafuze. 1987. Amniotic basement membrane: a barrier to neutrophil invasion. Am. J. Obstet. Gynecol. 156:1130-1136.

65. Messadi, D. V., J. S. Pober, W. Fiers, M. A. Gimbrone, Jr., and
G. F. Murphy. 1987. Induction of an activation antigen on postcapillary venular endothelium in human skin organ culture. J. Immunol. 139:1557-1562.

66. Schor, A. M., S. L. Schor, and T. D. Allen. 1983. Effects of culture conditions on the proliferation, morphology and migration of bovine aortic endothelial cells. J. Cell Sci. 62:267-285.

67. Brown, A. F. 1982. Neutrophil granulocytes: adhesion and locomotion on collagen substrata and in collagen matrices. J. Cell Sci. 58:455-467.

68. Grinnell, F. 1982. Migration of human neutrophils in hydrated collagen lattices. J. Cell Sci. 58:95-108.

69. Islam, L. N., I. C. McKay, and P. C. Wilkinson. 1985. The use of collagen or fibrin gels for the assay of human neutrophil chemotaxis. J. Immunol. Methods. 85:137-151.

70. Liotta, L. A. 1986. Tumor invasion and metastases-role of the extracellular matrix: Rhoads memorial award lecture. Cancer Res. 46:1-7.

71. Majno, G., and G. E. Palade. 1961. The effect of histamine and serotonin on vascular permeability: an electron microscopic study. $J$. Biophys. Biochem. Cytol. 11:571-605.

72. Cochrane, C. G. 1968. Immunologic tissue injury mediated by neutrophilic leukocytes. Adv. Immunol. 9:97-162.

73. Crawford, J. P., H. Z. Movat, J. O. Minta, and M. Opas. 1985. Acute inflammation induced by immune complexes in the microcirculation. Exp. Mol. Pathol. 42:175-193.

74. Milks, L. C., G. P. Conyers, and E. B. Cramer. 1986. The effect of neutrophil migration on epithelial permeability. J. Cell Biol. 103:2729-2738.

75. Nash, S., J. Stafford, and J. L. Madara. 1987. Effects of polymorphonuclear leukocyte transmigration on the barrier function of cultured intestinal epithelial monolayers. J. Clin. Invest. 80:11041113.

76. Pipoly, D. J., and E. C. Crouch. 1987. Degradation of native type IV procollagen by human neutrophil elastase: implications of leukocyte-mediated degradation of basement membranes. Biochemistry 26:5748-5754.

77. Heiple, J. M., and L. Ossowski. 1986. Human neutrophil plasminogen activator is localized in specific granules and is translocated to the cell surface by exocytosis. J. Exp. Med. 164:826-840.

78. Wachtfogel, Y. T., W. Abrams, U. Kucich, G. Weinbaum, M. Schapira, and R. Colman. 1988. Fibronectin degradation products containing the cytoadhesive tetrapeptide stimulate human neutrophil degranulation. J. Clin. Invest. 81:1310-1316.

79. Kalebic, T., S. Garbisa, B. Glaser, and L. A. Liotta. 1983. Basement membrane collagen: degradation by migrating endothelial cells. Science (Wash. DC). 221:281-283.

80. Laug, W. E., M. E. Weinblatt, and P. A. Jones. 1985. Endothelial cells degrade extracellular matrix proteins produced in vitro. Thromb. Haemostasis 54:498-502.

81. Herron, G. S., Z. Werb, K. Dwyer, and M. J. Banda. 1986. Secretion of metalloproteinases by stimulated capillary endothelial cells. J. Biol. Chem. 261:2810-2813.

82. Pepper, M. S., J.-D. Vassalli, R. Montesano, and L. Orci. 1987. Urokinase-type plasminogen activator is induced in migrating capillary-endothelial cells. J. Cell Biol. 105:2535-2541.

83. de Groot, P. G., J. H. Reinders, and J. J. Sixma. 1987. Perturbation of human endothelial cells by thrombin or PMA changes the reactivity of their extracellular matrix towards platelets. J. Cell Biol. 104:697-704.

84. Doukas, J., H. B. Hechtman, and D. Shepro. 1988. Endothelial-secreted arachidonic acid metabolites modulate polymorphonuclear leukocyte chemotaxis and diapedesis in vitro. Blood. 71:771-779.

85. Yurchenco, P. D., and G. C. Ruben. 1987. Basement membrane structure in situ. Evidence for lateral associations in the type IV collagen network. J. Cell Biol. 105:2559-2568.

86. Hurley, J. V. 1964. Acute inflammation: the effect of concurrent leucocytic emigration and increased permeability on particle retention by the vascular wall. Br. J. Exp. Pathol. 65:627-633. 